\title{
Laissez-Faire Leadership and Affective Commitment: the Roles of Leader-Member Exchange and Subordinate Relational Self-concept
}

\author{
Véronique Robert ${ }^{1} \cdot$ Christian Vandenberghe $^{1}$ (iD
}

Published online: 26 June 2020

(C) The Author(s) 2020

\begin{abstract}
Although the detrimental effects of laissez-faire leadership are well documented, research on the underlying mechanisms and the boundary conditions associated with these effects remains scarce. Using the identity orientation framework and social exchange theory, we propose that employees with stronger relational self-concepts are more likely to be affected by laissez-faire leadership. As these employees define themselves through dyadic relationships, they may react more negatively to laissez-faire leadership by diminishing their contributions to mutual goals and reducing their affective organizational commitment. These predictions were tested within a three-wave longitudinal study through structural equations modeling analyses with full information maximum likelihood estimation on a sample of employees from multiple organizations $(N=449)$. As predicted, the relational self-concept was associated with a stronger negative effect of laissez-faire leadership on the contribution dimension of leader-member exchange and a stronger negative indirect effect on affective organizational commitment. The implications of these findings for our understanding of the mechanisms related to laissez-faire leadership are discussed.
\end{abstract}

Keywords Laissez-faire leadership $\cdot$ Leader-member exchange $\cdot$ Affective organizational commitment $\cdot$ Relational self-concept . Identity orientation framework $\cdot$ Social exchange theory

Leadership has always been at the forefront of organizational research. Most research has focused on what constitutes a good leader, neglecting negative forms of leadership (Tepper, 2000, 2007; Schyns \& Schilling, 2013; Most research has focused on what constitutesMost research has focused on what constitutesZellars, Tepper, \& Duffy, 2002). However, according to the principle that "bad is stronger than good" (Baumeister, Bratslavsky, Finkenauer, \& Vohs, 2001), negative forms of leadership may be more influential than positive forms of leadership. It is thus surprising that this area of research has been underinvestigated (Hinkin \& Schriesheim, 2008a; Judge \& Piccolo, 2004). Despite recent interest into destructive leadership (Schyns \& Schilling, 2013), more passive yet destructive forms of leadership such as laissez-faire leadership did not receive the

Christian Vandenberghe

christian.vandenberghe@hec.ca

Véronique Robert

veronique.robert@hec.ca

1 HEC Montréal, 3000 chemin Côte Ste-Catherine, Montréal, Québec H3T2A7, Canada same attention (Che, Zhou, Kessler, \& Spector, 2017). Passive forms of leadership, which include laissez-faire as the most extreme passivity of leaders, can still have detrimental effects on employees and organizations (Hinkin \& Schriesheim, 2008a; Kelloway, Sivanathan, Francis, \& Barling, 2005; Skogstad, Einarsen, Torsheim, Aasland, \& Hetland, 2007). For example, laissez-faire leadership was found to be associated with reduced job satisfaction, leader effectiveness, satisfaction with the leader (Judge \& Piccolo, 2004), and performance (Yammarino, Spangler, \& Bass, 1993). Similarly, a study (Skogstad et al., 2014) found laissez-faire leadership to be the sole (negative) leadership predictor of job satisfaction over a 2-year period. However, despite being one of the most prevalent forms of negative leadership in modern organizations (Aasland, Skogstad, Notelaers, Nielsen, \& Einarsen, 2010), laissez-faire leadership has been understudied (Skogstad, Hetland, Glasø, \& Einarsen, 2014). Organizational research would gain from investigating this particular type of (negative) leadership given both its prevalence and its likely detrimental effects on employees and organizations.

Laissez-faire leadership is part of the full-range leadership model (Avolio, 2011), one of the most established (Den Hartog, Van Muijen, \& Koopman, 1997) and popular models 
of leadership (Dumdum, Lowe, \& Avolio, 2002; Judge \& Piccolo, 2004; Lowe, Kroeck, \& Sivasubramaniam, 1996), which also comprises transformational and transactional dimensions. Defined as avoidance and abdication of one's responsibilities (Hinkin \& Schriesheim, 2008b; Skogstad, Hetland, et al., 2014), "laissez-faire has been consistently found to be the least satisfying and least effective management style" (Bass \& Bass, 2008, p. 145). However, as research has mainly focused on the direct effects of laissez-faire leadership (Bass \& Bass, 2008; Hinkin \& Schriesheim, 2008a), the mechanisms and contextual boundaries associated with these effects have received little attention, which is a gap we intend to fill with the current study. Our attempt at doing so resonates with the call for a more nuanced approach to laissez-faire leadership (Wong \& Giessner, 2018), as its effects may depend on the context (Yang, 2015; Yang \& Li, 2017). By shedding light on these processes, we take a step toward understanding how the detrimental effects of laissez-faire leadership can be reduced, hence providing clues for practitioners.

First, laissez-faire leadership may differentially affect individuals depending on their individual dispositions. An important individual disposition that has been considered in prior leadership research is the self-concept (Lord, Brown, \& Freiberg, 1999; van Knippenberg, van Knippenberg, De Cremer, \& Hogg, 2004). The self-concept refers to the ways in which people define themselves and, as such, influences the perceptions of oneself and others (Brewer \& Gardner, 1996; Lord \& Brown, 2004; Markus \& Wurf, 1987). It is composed of distinct motivations, sources of self-worth, and selfknowledge (Brickson, 2000). Multiple levels of the selfconcept have been identified, namely, the individual, relational, and collective levels (e.g., Brewer \& Gardner, 1996; Lord $\&$ Brown, 2004). Since leadership involves dyadic relationships between leaders and subordinates, a relational self-concept, which refers to the significance of dyadic relationships in people's life (Johnson \& Saboe, 2011), is a salient characteristic that may influence employee reactions to leaders (Brewer \& Gardner, 1996). Employees with a strong relational selfconcept are likely more affected by, and to react more strongly to, laissez-faire leadership because such leadership poses a threat to their goals, needs, and identity-defining relationship (Wisse \& Sleebos, 2016). The absence of decisions and interactions with the leader may violate their expectations that a leader should attend to work-related problems and their relational needs (Lord \& Brown, 2001). Therefore, individuals with strong relational self-concepts may experience laissezfaire leadership as disappointing, resulting in negative attitudes toward their supervisors and the organization.

Second, we explore the possibility that laissez-faire leadership may negatively affect the quality of the exchange relationship between employees and leaders. Leader-member exchange (LMX) theory suggests that leaders develop differential relationships with employees, ranging from low-quality to high- quality relationships (Boies \& Howell, 2006; Chen, He, \& Weng, 2018; Erdogan \& Bauer, 2010; Liden \& Graen, 1980). As laissez-faire leadership involves the abdication of one's responsibilities, it may result in reduced LMX, particularly among employees with strong relational self-concepts. As these individuals are more sensitive to expressions of support and recognition and the active involvement of their leaders in decisions (Brewer \& Gardner, 1996), laissez-faire leaders — because they do not attend to employees' relational needs - will not be able to entice them to cooperate and contribute to mutual goals (De Cremer, 2003). Among the dimensions of LMX (i.e., affect, loyalty, contribution, and professional respect; Liden \& Maslyn, 1998), one particularly reflects that "currency of exchange" (Dienesch \& Liden, 1986; Greguras \& Ford, 2006; Law, Wang, \& Hui, 2010; Maslyn \& Uhl-Bien, 2001) we allude to here. Specifically, the contribution dimension of LMX (i.e., the activity put forth toward mutual goals; Liden \& Maslyn, 1998) is most likely to be affected because laissezfaire leadership involves a failure to invest in the relationship with the employee. Thus, as a result of laissez-faire leadership, employees with strong relational self-concepts may be inclined to reduce their contributions to mutual goals. We further argue that a lack of contribution by these employees will in turn lead to reduced affective organizational commitment (AOC) because it is well established that relationships with supervisors have implications for attitudes toward the organization (Dulebohn, Bommer, Liden, Brouer, \& Ferris, 2012).

This study contributes to the leadership literature in several ways. First, we extend this literature by delving into the mechanisms and boundary conditions explaining how laissez-faire leadership negatively relates to AOC. Our focus is on examining the quality of the relationship between employees and leaders (i.e., LMX) as a primary reason why laissez-faire may affect AOC. Second, in doing so, we take a disaggregated approach to LMX and identify its contribution dimension as the most relevant aspect of LMX that should be affected by laissez-faire leadership. To further demonstrate the unique sensitivity of LMX's contribution dimension to laissez-faire leadership, this study shows in parallel that the other LMX dimensions (i.e., affect, loyalty, and professional respect) are not affected by laissez-faire leadership. Third, we examine employees' relational self-concepts as a boundary condition and, as such, depart from the leader-centric approaches that dominate the field (Schyns \& Schilling, 2013). The relational self-concept is used as an individual difference variable that magnifies the value that individuals attribute to dyadic relationships. Fourth, our focus on laissez-faire leadership as an antecedent to LMX and AOC breaks new ground by expanding the spectrum of negative antecedents to these constructs. Finally, our hypotheses were tested within a dynamic perspective as we controlled for the baseline levels of our mediator and outcome variables in a three-wave longitudinal study. Hypotheses are developed in the next sections. 


\section{Theoretical Framework and Hypotheses}

\section{Laissez-Faire Leadership}

Laissez-faire leadership is characterized by avoidance and inaction (Bass \& Bass, 2008; Avolio, 2011; Hinkin \& Schriesheim, 2008b; Skogstad, Hetland, et al., 2014). Laissez-faire leaders avoid making decisions, abdicate their responsibilities, delay actions, and refrain from using the authority associated with their roles (Bass \& Bass, 2008; Den Hartog et al., 1997). They also fail to provide feedback and recognition to subordinates (Hinkin \& Schriesheim, 2008b) and they tend to ignore followers' needs, as they do not deal with work-related problems (Yukl, 2010). These leaders do not take sides in disputes and are disorganized in dealing with priorities (Bass, 1998). Based on their survey, Aasland et al. (2010) noted that $21 \%$ of employees had experienced laissezfaire behaviors from their leaders during the previous six months, making laissez-faire the most prevalent form of negative leadership.

Neglecting one's responsibilities as a leader harms both the organization and the subordinates (Hinkin \& Schriesheim, 2008a; Skogstad et al., 2007). Laissez-faire leadership is not only ineffective but also destructive (Aasland et al., 2010; Einarsen, Aasland, \& Skogstad, 2007; Skogstad, Aasland, et al., 2014; Skogstad, Hetland, et al., 2014). Empirically, laissez-faire leadership has been found to be associated with reduced subordinate effort (Bass \& Stogdill, 1990), performance (Yammarino et al., 1993), job satisfaction, perceived leader effectiveness, and satisfaction with the leader (Judge \& Piccolo, 2004); increased stress and interpersonal conflicts (Skogstad et al., 2007); and more role ambiguity and role conflict (Skogstad et al., 2007; Skogstad, Hetland, et al., 2014). However, the inactivity characterizing laissez-faire leadership makes this style of leadership unique and distinct from other forms of negative leadership because its negative consequences result from the absence of constructive behaviors rather than from the presence of destructive ones (Kelloway, Mullen, \& Francis, 2006). Therefore, further inquiry into laissez-faire leadership is warranted.

\section{Laissez-Faire Leadership and Leader-Member Exchange}

We posit that a primary mechanism through which laissezfaire leadership may affect employees pertains to the quality of the exchange relationship with the leader or LMX (e.g., Buch, Martinsen, \& Kuvaas, 2015). Indeed, employees may be unmotivated to uphold a good relationship with a leader with whom they expect to have limited interactions (van Knippenberg \& Steensma, 2003). According to social exchange theory (Blau, 1964), employees invest in a relationship when they feel that contributing their time and energy may lead to reciprocal exchanges. However, laissez-faire leaders fail to provide resources such as information, challenging task assignments, and autonomy-supportive conditions. In such circumstances, employees may feel they are not receiving their due in the relationship with their leader, which may reduce their desire to engage in tasks and duties beyond what is formally required.

The exchange of resources and opportunities is central to LMX development (Liden \& Graen, 1980) and depending on the resources/opportunities that are valued by the exchange partners (Graen \& Cashman, 1975), different "currencies of exchange" may be salient to LMX (Dienesch \& Liden, 1986; Law et al., 2010). Liden and Maslyn (1998) (see also Dienesch \& Liden, 1986) developed a conceptualization of LMX comprising four dimensions reflecting different aspects of these currencies: affect (i.e., mutual affection based on interpersonal attraction), loyalty (i.e., the expression of public support for the goals and the other member's character), contribution (i.e., the amount, direction and quality of work toward mutual goals), and professional respect (i.e., the perception of reputation and excellence). While many studies have adopted a unidimensional view of LMX (Dulebohn, $\mathrm{Wu}, \&$ Liao, 2017), it is likely that high LMX is derived from different dimensions depending on circumstances (Liden \& Maslyn, 1998; Maslyn \& Uhl-Bien, 2001), such as the leadership style adopted (Lee, 2005). Thus, the very nature of laissez-faire leadership may indicate which dimension of LMX is more likely to be solicited.

As laissez-faire leadership involves unfulfilled responsibilities, these leaders set standards that lower the value of workrelated exchanges (Liden \& Maslyn, 1998). Therefore, the task-related behaviors of employees (Graen \& Scandura, 1987; Liden \& Maslyn, 1998; Maslyn \& Uhl-Bien, 2005) and employees' own efforts to develop LMX (Maslyn \& Uhl-Bien, 2001) may be limited. With laissez-faire leadership, the contribution dimension of LMX, which refers to the "perception of the amount, direction, and quality of work-oriented activity each member puts forth toward the mutual goals (explicit or implicit) of the dyad" (Dienesch \& Liden, 1986, p. 624), is likely affected (e.g., Lee, 2005). From the employee's perspective, LMX's contribution reflects the subordinate's willingness to help the leader and contribute to his or her goals. Following social exchange theory (Blau, 1964), laissez-faire leaders do not encourage subordinates to contribute to mutual goals over what is included in their job descriptions as they may think they do not receive their dues (e.g., support, recognition) in the relationship with the leader. It is also likely that LMX's contribution dimension is mostly affected in response to laissez-faire leadership because it is the only dimension that reflects the exchange from a behavioral perspective. The other dimensions (affect, loyalty, and respect) do not refer to the behavioral component of the exchange relationship. Laissez-faire leaders echo to this 
dimension by not taking actions that would signal support and recognition to subordinates. It is thus the absence of constructive behaviors (Kelloway et al., 2006) in laissez-faire leaders that makes LMX's contribution mostly affected.

However, as theory has stipulated that because of limited resources and time, leaders differentiate among followers (Dansereau Jr., Graen, \& Haga, 1975; Graen \& Cashman, 1975; Graen \& Scandura, 1987; Liden \& Graen, 1980; Maslyn \& Uhl-Bien, 2005), distinct LMX relationships are found across followers (Boies \& Howell, 2006; Chen et al., 2018; Erdogan \& Bauer, 2010; Henderson, Liden, Glibkowski, \& Chaudhry, 2009; Herdman, Yang, \& Arthur, 2017; Le Blanc \& González-Romá, 2012; Liden, Erdogan, Wayne, \& Sparrowe, 2006; Wu, Tsui, \& Kinicki, 2010). Thus, while laissez-faire leadership may lend itself to poor LMX relationships, particularly in regard to its contribution dimension, there may be variability in the extent to which employees' relationships with their leaders are impacted by laissez-faire leadership. One factor that may explain this variability relates to employees' self-concepts (Jackson \& Johnson, 2012), which we now discuss.

\section{Levels of the Self-concept}

Leadership practices do not operate in a vacuum (Epitropaki, Kark, Mainemelis, \& Lord, 2017). Rather, leaders' behavior interacts with the characteristics of followers (Padilla, Hogan, \& Kaiser, 2007). Such interactionist perspective suggests that a better understanding of leaders' influence can be gained by accounting for followers' expectations about leaders' behavior. To illustrate such individual differences, research has identified the self-concept as an important background construct that guides individuals' reactions to leaders' behavior (Lord et al., 1999). The self-concept is a self-regulatory mechanism that drives self-esteem and organizes self-relevant knowledge (Brewer \& Gardner, 1996). As a chronic representation of identity that promotes a self-definition anchored at the individual, relational, or collective level, the self-concept influences how people feel, think, and behave (Lord \& Brown, 2004; Markus \& Wurf, 1987). Research has shown that the levels of the self-concept influence employees' interpretations of leaders' behavior (Chang \& Johnson, 2010; Jackson \& Johnson, 2012; Lord \& Brown, 2004; Lord et al., 1999; Wu et al., 2010) and influence leaders' effectiveness (Hogg, Martin, \& Weeden, 2003; Lord \& Brown, 2004; Lord et al., 1999). By extension, we expect the self-concept to play a similar role regarding laissez-faire leadership.

Three levels of the self-concept have been identified (Brewer \& Gardner, 1996; Brickson, 2000; Johnson, Selenta, \& Lord, 2006; Lord \& Brown, 2004; Lord et al., 1999; Sedikides \& Brewer, 2001; Sedikides, Gaertner, \& O'Mara, 2011). The collective self-concept involves the selfdefinition derived from belonging to groups such as organizations or teams; the relational self-concept involves a focus on dyadic relationships as a source of identity; and the individual self-concept stresses an individual's uniqueness and self-interests (Brewer \& Gardner, 1996; Lord et al., 1999; Sedikides \& Brewer, 2001; van Knippenberg et al., 2004). Even though the different levels may coexist within the same person, individuals differ regarding the importance they place on each level of the self-concept (Brewer \& Chen, 2007).

Although the employee self-concept has been shown to exert a moderating role on leader effectiveness, this effect has been mostly studied using the collective self-concept (Hogg, 2001; Hogg \& van Knippenberg, 2003; Lord et al., 1999; Lord \& Brown, 2004; van Knippenberg \& Hogg, 2003). However, the relational self-concept has been largely overlooked. This is surprising because individuals are more likely to be affected by threats at the relational level than by those at the collective level of the self (Gaertner et al., 2012). Moreover, the relational identity becomes relevant when one looks at the outcomes of the leader's actions from the perspective of the dyadic relationship (i.e., LMX; Chang \& Johnson, 2010; Lord et al., 1999; Schyns \& Day, 2010). As subordinates with strong relational self-concepts place a premium on dyadic exchanges (Wisse \& Sleebos, 2016) and affective bonds with specific others (Brewer \& Gardner, 1996), their self-worth should be particularly dependent on how their leader responds to their relational expectations.

\section{Moderating Role of the Relational Self-concept}

Reliable role performance is rooted in how interactions between leader and subordinate unfold and whether the partners' role expectations are fulfilled (Graen \& Scandura, 1987). By abdicating the responsibilities related to their role, laissez-faire leaders violate subordinates' role expectations (Eagly, Johannesen-Schmidt, \& van Engen, 2003; Hinkin \& Schriesheim, 2008a; Skogstad et al., 2007). However, the discrepancy between employees' expectations and leaders' behavior is likely stronger among employees with a relational self-identity because these employees are particularly sensitive to the fulfillment of role expectations (Andersen \& Chen, 2002). Indeed, these employees have important relational needs, entertain affective ties with significant others (Brewer \& Gardner, 1996; Flynn, 2005; Wisse \& Sleebos, 2016), and expect dyadic partners to engage in behaviors that satisfy their relational expectations. Therefore, they are likely to feel frustrated if their leader does not engage in actions liable to maintain the relationship vivid and constructive.

Laissez-faire leaders may discourage employees from investing resources in LMX (Aryee, Chen, Sun, \& Debrah, 2007; Xu, Huang, Lam, \& Miao, 2012). Per the tenets of social exchange theory (Blau, 1964), a balance is expected between inputs and contributions in LMX relationships 
(Kuvaas, Buch, Dysvik, \& Haerem, 2012). As laissez-faire leaders fall short of maintaining balanced relationships (e.g., they delay decisions and do not take actions when needed), employees with relational self-concepts would experience this as a threat to their identity (Brewer \& Gardner, 1996; Flynn, 2005). This is so because they tend to define themselves in terms of their relations with others (Ferris, Yan, Lim, Chen, \& Fatimah, 2016). Employees with a relational self-concept may thus experience their sense of self-worth as being undermined by the laissez-faire behavior of their leader (Swann Jr., ChangSchneider, \& Angulo, 2007), which would lower their motivation to cooperate with him or her (Tyler, 2003). As a result, employees with a relational self-concept may thrive to protect themselves by reducing their contribution to the relationship (Flynn, 2005). Thus, the lack of reciprocity (Herdman et al., 2017) instilled by laissez-faire behaviors would encourage these employees to reduce their contributions to the attainment of mutual goals, which represents an integral aspect of LMX (Maslyn \& Uhl-Bien, 2001). In sum, these employees would fall back on formal and contractual obligations (Erdogan \& Liden, 2002; Liden \& Graen, 1980; Shore, Bommer, Rao, \& Seo, 2009).

Hypothesis 1: The employee's relational self-concept will moderate the relationship between laissez-faire leadership and LMX-Contribution such that this relationship will be stronger (vs. weaker) and negative when the relational self-concept is high (vs. low).

\section{Affective Organizational Commitment}

AOC reflects an emotional attachment to and identification with one's organization (Allen \& Meyer, 1990; Meyer \& Allen, 1997). It is the most impactful component of organizational commitment (Meyer \& Herscovitch, 2001) and the most robust predictor of work-related behaviors (Lavelle, Rupp, \& Brockner, 2007). Multiple studies have reported a positive relationship between LMX and AOC (Dulebohn et al., 2012; Gerstner \& Day, 1997; Liden \& Maslyn, 1998; Liden, Wayne, \& Sparrowe, 2000). AOC is one the most studied outcomes of LMX (Eisenberger et al., 2010; Meyer, 2016; Wayne et al., 2009). Liden and Maslyn (1998) theorized that the contribution dimension of LMX reflects a willingness to complete tasks that go beyond one's job description and benefit the organization as a whole. Thus, more specifically, LMX-Contribution should be positively related to AOC (Greguras \& Ford, 2006; Lee, 2005; Shore \& Wayne, 1993). Indeed, since leaders carry out responsibilities and make decisions on behalf of the organization, they are seen as representing the organization (Skarlicki \& Folger, 1997) and as agents connecting employees to the organization (Seers \& Graen, 1984). Therefore, positive exchange relationships between leaders and employees as reflected in strong LMX-
Contribution should ultimately result in stronger AOC (Eisenberger, Aselage, Sucharski, \& Jones, 2004).

As argued above, we expect a higher relational self-concept to be associated with a more negative relationship between laissez-faire leadership and LMX-Contribution. Following a social exchange account (Blau, 1964), this effect should extend to the indirect relationship between laissez-faire leadership and AOC. That is, employees with strong relational selfconcepts should feel that their needs and expectations are unfulfilled when their leaders abdicate their responsibilities because dyadic relationships occupy a central place in these individuals' self-definitions. This feeling would encourage them to reduce their contribution to mutual goals. In turn, this decreased contribution would penalize employee commitment to the organization because the relative quality of the exchange relationship with the supervisor tends to generalize to the attachment to the organization (Eisenberger, Stinglhamber, Vandenberghe, Sucharski, \& Rhoades, 2002).

Hypothesis 2: The employee's relational self-concept will moderate the indirect relationship between laissez-faire leadership and AOC through LMX-Contribution such that this indirect relationship will be stronger (vs. weaker) and negative when the relational self-concept is high (vs. low).

\section{Method}

\section{Sample and Procedure}

Data were gathered through survey questionnaires that were administered in three waves with intervals of four months. Participants were recruited through the alumni association of a French business school. Prospective participants received an email inviting them to participate in an online study of job attitudes based on three questionnaires administered over several months. They were informed of the study objectives and ensured that participation was voluntary and responses would be kept confidential. The criteria for participation were having (a) salaried employment and (b) an identifiable supervisor. To encourage participation, the respondents had the opportunity to make a $\$ 5$ gift to a charity of their choice at each wave of the surveys. The questionnaires were answered in French or English. At time 1, we measured the self-concept levels, laissez-faire leadership, LMX dimensions, AOC, and demographics, among other variables. The LMX dimensions were measured again at time 2 , while AOC was also measured at time 3. The baseline (i.e., time 1) levels of the mediator (i.e., LMX-Contribution) and outcome (i.e., AOC) variables were controlled for while examining the moderation effect of the relational self-concept in the relationships among laissez-faire leadership, LMX-Contribution, and AOC. This approach provided a strong test of the longitudinal moderated mediation effects (Maxwell \& Cole, 2007). 
Excluding careless respondents $(n=4)$ and participants who left supervisors or organizations during the study period $(n=60)$, there remained 449 respondents at time 1, 182 at time 2 , and 120 at time 3 (i.e., $27 \%$ response rate). We first examined whether respondent attrition across time was randomly distributed. Specifically, we conducted a logistic regression analysis with time 1 self-concept levels, laissez-faire leadership, LMX dimensions, AOC, and demographics predicting the probability of remaining in the sample at time 3 (Goodman $\&$ Blum, 1996). The logistic regression model was nonsignificant $\left(\chi^{2}(13)=15.15, n s\right)$ and none of the predictors was significant, indicating random attrition. Because the data were missing completely at random across time, we used full information maximum likelihood (FIML) estimation within structural equations modeling (see Results section) to test hypotheses (Ployhart \& Vandenberg, 2010). This estimation procedure uses all the available information from the covariance matrix $(N=449)$ and is the recommended method for dealing with missing data (Newman, 2009).

In the final sample used for analyses, age averaged 37.67 years $(S D=9.00)$, organizational tenure averaged 6.07 years $(S D=5.67)$, and tenure with the supervisor averaged 2.95 years $(S D=2.28)$. Most of the participants were women (63\%), worked full-time $(92 \%)$, had a graduate-level education (94\%), and were employed in organizations of 1000 or more employees $(56 \%)$. They worked in various industries, such as finance and insurance $(15 \%)$, professional, scientific and technical services $(11 \%)$, manufacturing (7\%), health care and social assistance $(5 \%)$, retail trade $(5 \%)$, and information and cultural industries (4\%).

\section{Measures}

When needed, French versions of the English scales were created using a translation-back-translation procedure (Schaffer \& Riordan, 2003). Responses were obtained on a 5-point Likert scale ranging from 1 (strongly disagree) to 5 (strongly agree), unless otherwise specified.

\section{Laissez-Faire Leadership}

We measured laissez-faire leadership at time 1 using a 7item version (Hinkin \& Schriesheim, 2008a, 2008b) of the laissez-faire scale from the Multifactor Leadership Questionnaire 5X (Bass \& Avolio, 1991). A sample item is "[In the past few weeks] my immediate supervisor avoided making decisions about my work," with response options of 1 (strongly disagree) to 5 (strongly agree). Cronbach's alpha for this scale was .93.

\section{LMX-Contribution}

Participants answered the 12-item multidimensional measure of LMX (LMX-MDM) developed by Liden and Maslyn (1998) at time 1 and time 2, which contains four 3-item scales pertaining to the four LMX dimensions. The internal consistency for the 3-item LMX-Contribution scale was . 79 at time 1 and .80 at time 2. A sample item is "I do work for my supervisor that goes beyond what is specified in my job description." For exploratory purposes, we also measured the other LMX dimensions using their respective 3-item scales: affect (e.g., "I like my supervisor very much as a person"; $\alpha=.90$ at time 1 and .91 at time 2); loyalty (e.g., "My supervisor would defend me to others in the organization if I made an honest mistake"; $\alpha=.91$ at time 1 and .90 at time 2); and professional respect (e.g., "I admire my supervisor's professional skills"; $\alpha=.94$ at time 1 and .95 at time 2).

\section{$\mathrm{AOC}$}

We measured $\mathrm{AOC}$ at time 1 and time 3 using an adapted version (Bentein, Vandenberg, Vandenberghe, \& Stinglhamber, 2005) of Meyer, Allen, and Smith's (1993) 6item scale that was developed for international replications (cf., Meyer, Barak, \& Vandenberghe, 1996). A typical item is "I feel emotionally attached to this organization." The alpha coefficient for this scale was .93 at time 1 and time 3 .

\section{Relational Self-concept}

The relational self-concept was measured at time 1 through a 5 -item scale developed by Selenta and Lord (2005) and used in Johnson et al. (2006). A factor analysis of the scale items indicated that one item ("Knowing that a close other acknowledges and values the role that I play in their life makes me feel like a worthwhile person") had a low loading on the factor $(<.40)$ and reduced its internal consistency. Hence, we dropped that item from the scale. The remaining 4-item scale had a reliability of .71. A sample item is "If a friend was having a personal problem, I would help him/her even if it meant sacrificing my time or money."

\section{Control Variables}

While testing our hypotheses and model, we controlled for the individual and collective levels of the self-concept, as other researchers have done (e.g., Johnson \& Chang, 2008; Johnson et al., 2006). Indeed, as the three levels of the self-concept are generally correlated with one another (Kashima \& Hardie, 2000), controlling for the individual and collective selfconcepts helps avoid confounding effects. The individual $(\alpha=.82)$ and collective $(\alpha=.77)$ self-concepts were each measured at time 1 by a 5 -item scale from Selenta and Lord 
(2005) (see also Johnson et al., 2006). Sample items include "I often compete with my friends" and "It is important to me to make a lasting contribution to groups that I belong to," respectively.

\section{Results}

\section{Confirmatory Factor Analyses}

First, as a preliminary test, we used confirmatory factor analysis (CFA) through Mplus 7.31 (Muthén \& Muthén, 2010) and maximum likelihood (ML) estimation to examine the dimensionality of the LMX measure at time 2. We allowed the errors of items 7 and 8 of the scale to correlate, which is recommended when there is wording similarity (Marsh et al., 2010, 2013). The four-factor model of time 2 LMX yielded a good fit $\left(\chi^{2}(47)=87.00, \mathrm{CFI}=.98, \mathrm{TLI}=.97\right.$, RMSEA $=.068$, SRMR $=.043$ ) and outperformed a onefactor model $\left(\Delta \chi^{2}(6)=599.09, p<.001\right)$, supporting the idea of treating LMX dimensions (e.g., LMX-Contribution) separately. Similarly, the eight-factor model including the four LMX dimensions at time 1 and time 2 yielded a good fit $\left(\chi^{2}(212)=558.06, \mathrm{CFI}=.95, \mathrm{TLI}=.93, \mathrm{RMSEA}=.06\right)$ and outperformed a two-factor model (time 1 LMX vs. time 2 LMX) $\left(\chi^{2}(27)=1717.26, p<.001\right)$ and a one-factor model $\left(\chi^{2}(28)=2124.89, p<.001\right)$.

Second, we tested the distinctiveness of our variables within the hypothesized eight-factor model (i.e., time 1 laissezfaire leadership, time 1 self-concept levels, time 1 LMXContribution, time 1 AOC, time 2 LMX-Contribution, and time 3 AOC) and compared this model with more parsimonious models using a nested sequence approach (Bentler \& Bonett, 1980). The FIML method was used because it relies on all the available information from the covariance matrix (e.g., Enders, 2010; Fitzmaurice, Laird, \& Ware, 2004; Graham, 2009, 2012) and is the recommended approach in longitudinal research when respondent attrition across time is random (Ployhart \& Vandenberg, 2010). The errors of parallel items were allowed to correlate across time (Geiser, 2012). In addition, the errors of two pairs of items of the same constructs were allowed to correlate within time due to wording similarity (Marsh et al., 2010, 2013) (i.e., laissez-faire: items 1 and 2; individual self-concept: items 1 and 5). These specifications were incorporated in the test of the longitudinal model (Little, 2013).

The CFA results are reported in Table 1 . The hypothesized eight-factor model yielded a good fit $\left(\chi^{2}(663)=1373.00\right.$, $\mathrm{CFI}=.92, \mathrm{TLI}=.91, \mathrm{RMSEA}=.05)$. Moreover, this model was superior to any simpler model obtained by merging specific factors $(p<.01)$. Our variables were thus distinguishable. As evidence of convergent validity, in the eight-factor model, loadings were significant $(p<.001)$ and sizeable (standardized factor loadings ranged from .48 to .90$)$.

\section{Measurement Invariance}

Because our theoretical model controlled for time 1 LMXContribution and AOC, we needed to establish that their measurement was invariant across time to ensure that the construct meaning remained stable (Cole \& Maxwell, 2003; Millsap, 2011). A sequential approach was adopted (e.g., Vandenberg \& Lance, 2000) where increasingly stringent constraints were added to the CFA model of LMXContribution and AOC. Robust maximum likelihood (MLR) was used to test measurement invariance. The results are shown in Table 2. As we proceeded to test the sequence of constraints from configural invariance, to weak invariance (i.e., loadings), strong invariance (i.e., loadings and thresholds), and strict invariance (i.e., loadings, thresholds, and uniquenesses), the Satorra-Bentler scaled $\chi^{2}$ values were nonsignificant at each step for both LMX-Contribution and AOC. ${ }^{1}$ This finding indicates strict invariance for both variables across time, stable psychometric properties, and suitability for longitudinal analysis (Byrne, Shavelson, \& Muthén, 1989; Cheung \& Lau, 2012). Thus, these specifications were added to the longitudinal tests of our hypotheses.

\section{Descriptive Statistics and Correlations}

Descriptive statistics, correlations and reliability coefficients are reported in Table 3. Laissez-faire leadership was negatively related to time $2 \operatorname{LMX}(r=-.22, p<.01)$ but unrelated to time 3 AOC $(r=-.15, n s)$. Time 2 LMX-Contribution was positively related to time $3 \mathrm{AOC}(r=.36, p<.01)$. The relational self-concept was unrelated to laissez-faire leadership $(r=-.04, n s)$ and time 2 LMX-Contribution $(r=.04, n s)$ but positively correlated with time $3 \mathrm{AOC}(r=.18, p<.05)$.

\section{Hypothesis Testing}

We tested our hypotheses through latent moderated structural equation modeling (LMS; Klein \& Moosbrugger, 2000; Maslowsky, Jager, \& Hemken, 2015; Sardeshmukh \& Vandenberg, 2017) and maximum likelihood (i.e., FIML) estimation using numerical integration and raw data. We used the XWITH command in Mplus and robust standard errors estimation. By considering the measurement errors of the observed variables and factoring in the nonnormally distributed interactions of the latent variables, the LMS approach generates reliable estimates and unbiased standard errors, and has

\footnotetext{
${ }^{1}$ Note that we did not allow the errors of T1 item 1 and T2 item 1 to correlate in the invariance tests of the LMX-Contribution scale across time because the models including that specification did not converge.
} 
Table 1 Fit indices for confirmatory factor analysis models

\begin{tabular}{|c|c|c|c|c|c|c|c|}
\hline & $\chi^{2}$ & $d f$ & CFI & TLI & RMSEA & $\Delta \chi^{2}$ & $\Delta d f$ \\
\hline 1. Hypothesized eight-factor solution & $1373.00 *$ & 663 & .92 & .91 & .05 & - & - \\
\hline 2. Seven-factor solution, combining $\mathrm{T} 1 \mathrm{AOC}$ and $\mathrm{T} 3 \mathrm{AOC}$ & $1653.69 *$ & 670 & .88 & .87 & .06 & $280.69^{*}$ & 7 \\
\hline 3. Seven-factor solution, combining T1 LMX-C and T2 LMX-C & $1498.81 *$ & 670 & .90 & .89 & .05 & $125.81 *$ & 7 \\
\hline 4. Seven-factor solution, combining T1 laissez-faire leadership and T2 LMX-C & $1581.26^{*}$ & 670 & .89 & .88 & .06 & $208.25^{*}$ & 7 \\
\hline 5. Seven-factor solution, combining T1 RSC and CSC & $1611.18 *$ & 670 & .89 & .88 & .06 & $238.18^{*}$ & 7 \\
\hline 6. Seven-factor solution, combining T1 RSC and ISC & $2162.32 *$ & 670 & .82 & .81 & .07 & $789.32 *$ & 7 \\
\hline 7. Seven-factor solution, combining T2 LMX-C and T3 AOC & $1549.96^{*}$ & 670 & .90 & .89 & .05 & $176.96^{*}$ & 7 \\
\hline 8. Six-factor solution, combining T1 LMX-C with T2 LMX-C, and T1 AOC with T3 AOC & $1774.96 *$ & 676 & .87 & .86 & .06 & $401.96^{*}$ & 13 \\
\hline 9. Six-factor solution, combining all self-concept variables & $2402.76^{*}$ & 676 & .80 & .78 & .08 & $1029.75^{*}$ & 13 \\
\hline 10. One-factor solution, combining all variables & $6102.10 *$ & 694 & .36 & .32 & .13 & $4729.10^{*}$ & 31 \\
\hline
\end{tabular}

$N=449$, based on full information maximum likelihood estimation. $d f$, degrees of freedom; $C F I$, comparative fit index; TLI, Tucker-Lewis index; $R M S E A$, root mean square error of approximation; $T 1$, time $1 ; T 2$, time 2; T3, time 3; $A O C$, affective organizational commitment; $L M X$ - $C$, leadermember exchange, contribution dimension; RSC, relational self-concept; CSC, collective self-concept; ISC, individual self-concept

$* p<.01$

increased power to detect interaction effects (Cheung \& Lau, 2017; Klein \& Moosbrugger, 2000; Sardeshmukh \& Vandenberg, 2017). Thus far, LMS is the most efficient and unbiased approach to testing interactions among latent variables (Klein \& Moosbrugger, 2000; Sardeshmukh \& Vandenberg, 2017; Schermelleh-Engel, Werner, Klein, \& Moosbrugger, 2010).

As LMS does not assume multivariate normality, commonly used fit indices (e.g., RMSEA, CFI, TLI; Maslowsky et al., 2015) are not provided. We therefore followed the recommended two-step approach (Dimitruk, Schermelleh-Engel, Kelava, \& Moosbrugger, 2007; Sardeshmukh \& Vandenberg, 2017) to test our hypotheses. We first assessed the fit of a baseline model where the interaction between laissez-faire and the relational self-concept was constrained to zero. We then compared this model with a model including the interaction term. The two models were compared using a log-likelihood difference test
(D-2LL; Dimitruk et al., 2007) and the Akaike information criterion (AIC) and Bayesian information criterion (BIC) indices (Sardeshmukh \& Vandenberg, 2017). A significant D-2LL value indicates that the augmented model should be retained as the best model (Dimitruk et al., 2007), while smaller values for the AIC and BIC are needed to ensure that there is no dramatic loss of information relative to the baseline model (Sardeshmukh \& Vandenberg, 2017). We used 95\% confidence intervals (CIs) from 5000 bootstrap samples (MacKinnon, Lockwood, \& Williams, 2004) in Mplus and the ML estimator for testing the significance of the moderation and moderated mediation effects predicted in Hypotheses 1-2.

Hypothesis 1. The baseline model including the main effects of laissez-faire leadership and relational self-concept on time 2 LMX-Contribution, controlling for time 1 LMXContribution and the main effects of individual and collective self-concepts, yielded a good fit to the data $\left(\chi^{2}(311)=636.83\right.$,

Table 2 Tests of measurement invariance across time

\begin{tabular}{|c|c|c|c|c|c|c|c|c|}
\hline & $\chi^{2}$ & $d f$ & CFI & TLI & RMSEA & Model comparison & $S B \Delta \chi^{2}$ & $\Delta d f$ \\
\hline \multicolumn{9}{|l|}{ LMX-Contribution } \\
\hline Model 1: Configural invariance & 9.89 & 6 & .99 & .98 & .04 & - & & - \\
\hline Model 2: Weak invariance (loadings) & 11.18 & 8 & 1.00 & .99 & .03 & 2 vs. 1 & 1.27 & 2 \\
\hline Model 3: Strong invariance (loadings, thresholds) & 11.61 & 10 & 1.00 & 1.01 & .02 & 3 vs. 2 & 0.24 & 2 \\
\hline $\begin{array}{l}\text { Model 4: Strict invariance (loadings, thresholds, uniquenesses) } \\
\text { AOC }\end{array}$ & 14.89 & 13 & 1.00 & 1.01 & .02 & 4 vs. 3 & 3.29 & 3 \\
\hline Model 1: Configural invariance & $186.76^{*}$ & 47 & .94 & .92 & .08 & - & & - \\
\hline Model 2: Weak invariance (loadings) & $196.96^{*}$ & 52 & .94 & .92 & .08 & 2 vs. 1 & 4.94 & 5 \\
\hline Model 3: Strong invariance (loadings, thresholds) & $205.70^{*}$ & 57 & .94 & .93 & .08 & 3 vs. 2 & 7.86 & 5 \\
\hline Model 4: Strict invariance (loadings, thresholds, uniquenesses) & $206.70^{*}$ & 63 & .94 & .94 & .07 & 4 vs. 3 & 2.01 & 6 \\
\hline
\end{tabular}

Full information maximum likelihood estimation was used. $d f$, degrees of freedom; CFI, comparative fit index; TLI, Tucker-Lewis index; RMSEA, root mean square error of approximation; $S B$, Santorra-Bentler scaled

$* p<.05$ 
$\mathrm{CFI}=.93$, TLI $=.92$, RMSEA $=.05)$. However, the moderated model outperformed the baseline model (D-2LL $(1)=$ $10.29, p<.01)$. Moreover, this model displayed smaller values for the AIC $(27,594.32$ vs. 27,601.25) and BIC (27,984.48 vs. $27,987.31)$. Thus, the moderated model was retained. As shown in Table 4, the interaction between laissez-faire leadership and the relational self-concept predicting LMX-Contribution was significant $(B=-.67$, $S E=.28, p<.05)$. The interaction is graphed in Fig. 1. Laissez-faire leadership was significantly negatively related to LMX-Contribution $(B=-.34, S E=.15, p<.05)$ when relational self-concept was high (1 $S D$ above the mean) but unrelated to LMX-Contribution $(B=.26, S E=.14, n s)$ when relational self-concept was low (1 $S D$ below the mean). Moreover, the difference between these two relationships was significant $(B=-.60, S E=.25, p<.05)$. Interestingly, the relationship between laissez-faire leadership and LMXContribution was significantly negative $(p<.05)$ when relational self-concept had a standardized value of at least .245 but was significantly positive $(p<.05)$ when relational selfconcept had a standardized value of -.572 or lower. Hypothesis 1 is thus supported.

Hypothesis 2. The moderated mediation relationship predicted in Hypothesis 2 was tested following Sardeshmukh and Vandenberg's (2017) recommendations. We first specified a mediation model including (a) the main effects of laissez-faire leadership and relational self-concept on time 2 LMXContribution, controlling for time 1 LMX-Contribution, and on time $3 \mathrm{AOC}$, controlling for time $1 \mathrm{AOC}$, and (b) the effect of time 2 LMX-Contribution on time 3 AOC. Moreover, the model controlled for the main effects of the individual and collective self-concepts on time 2 LMX-Contribution and time 3 AOC. This baseline model showed an acceptable fit $\left(\chi^{2}(688)=1328.24, \mathrm{CFI}=.92, \mathrm{TLI}=.91, \mathrm{RMSEA}=.05\right) . \mathrm{We}$ then compared this model with a moderated mediation model in which relational self-identity moderated the first stage of the mediated relationship between laissez-faire leadership and time 3 AOC through time 2 LMX-Contribution. The latter model outperformed the baseline model (D-2LL $(1)=9.31$, $p<.01)$ and displayed smaller values for the AIC $(35,619.84$ vs. $35,627.67)$ and $\mathrm{BIC}(36,161.97$ vs. $36,165.69)$. Thus, this model was retained and used to examine the conditional indirect effects of interest.

Using bootstrapping, the indirect relationship between laissez-faire leadership and time 3 AOC through time 2 LMX-Contribution was found to be significantly negative $(B=-.05, S E=.03,95 \%$ CI $[-.111,-.002])$ when relational self-concept was high (1SD above the mean) but nonsignificant $(B=.04, S E=.02,95 \%$ CI $[-.004, .098])$ when relational self-concept was low (1 $S D$ below the mean) (Table 4). Moreover, the difference between these two relationships was significant $(B=-.09, S E=.05,95 \%$ CI $[-.197$, $-.007])$. Notably, the conditional indirect effect of laissez- faire leadership was significantly negative $(p<.05)$ when relational self-concept had a standardized value of at least .387 . Hypothesis 2 is thus supported. The path estimates associated with the moderated mediation model as obtained by standardizing the data before analysis (e.g., Klein \& Moosbrugger, 2000; Maslowsky et al., 2015) are reported in Fig. 2. ${ }^{2}$

\section{Additional Analyses}

We explored the possibility that a relational self-concept could moderate the indirect relationship between laissez-faire leadership and time 3 AOC through the other dimensions of (time 2) LMX, namely affect, loyalty, and professional respect. Using the same procedure as for testing Hypothesis 2, we found the baseline models to display a good fit (LMXAffect: $\chi^{2}(688)=1196.57$, CFI $=.94$, TLI $=.93$, RMSEA $=.04$; LMX-Loyalty: $\chi^{2}(688)=1167.63, \mathrm{CFI}=.94$,

\footnotetext{
${ }^{2}$ Although our study controlled for the baseline levels of the mediator (LMXContribution) and AOC, the data were not cross-lagged, making it possible that AOC drives LMX-Contribution over time. To examine this possibility, we used data from a separate sample to test a cross-lagged model of LMXContribution and AOC over a period of 6 months. These data were part of a larger project examining job attitudes and the study was conducted in French. Participants were recruited through convenience sampling from the network of the research team. The time 1 sample comprised 312 respondents. In this initial sample, 22 participants changed organizations and 37 participants changed supervisors before the time 2 survey (i.e., six months later), hence were dropped, reducing the sample to 253 individuals. In this sample, 119 participants provided usable responses at time 2 . We first examined whether attrition over time was randomly distributed by conducting a logistic regression analysis predicting the probability of remaining in (vs. being dropped from) the final sample among time 1 respondents $(N=253)$ using time 1 variables (i.e., LMX-Contribution and AOC) as predictors. The logistic regression model was nonsignificant $\left(\chi^{2}(2)=3.51, n s\right)$ and none of the predictors was significant. This indicates that data were missing completely at random (MCAR; Ployhart \& Vandenberg, 2010) over time, allowing us to examine our cross-lagged model using all the available information from the covariance matrix $(N=253)$ through the FIML method and MLR in Mplus (version 7.31 was used; Muthén \& Muthén, 2010). In the sample $(N=253), 63 \%$ of the participants were female, average age was 38.77 years $(S D=10.22)$, and average organizational tenure was 7.89 years $(S D=6.05)$. Participants worked in a variety of industries such as professional, scientific and technical services (23\%), health services and social assistance (18\%), and finance, insurance, real estate and public administration (16\%). AOC was measured using the same 6-item, adapted version of Meyer et al.'s (1993) original scale (Bentein et al., 2005) as in the main study. The same 3-item scale of LMX-Contribution from the LMX-MDM instrument (Liden \& Maslyn, 1998) as in the main study was also used. The internal consistency was good for both AOC $(\alpha \mathrm{s}=.88$ and .89 at time 1 and time 2, respectively) and LMX-Contribution ( $\alpha \mathrm{s}=.76$ and .74 at time 1 and time 2 , respectively). The strict invariance model was used for AOC and the weak invariance model was used for LMX-Contribution because adding further constraints revealed significant differences with less constrained models of invariance. Nonetheless, retaining weak invariance still allows testing the relations among latent constructs (Vandenberg \& Lance, 2000). The cross-lagged model yielded a good fit to the data $\left(\chi^{2}(141)=223.77, p<.001, \mathrm{CFI}=.95, \mathrm{TLI}=.95, \mathrm{RMSEA}=.05\right)$. In this model, time 1 LMX-Contribution was significantly related to time 2 AOC $(B=.24, S E=.09, p<.01)$, controlling for its autoregressive effect $(B=.67$, $S E=.08, p<.001)$. In contrast, time 1 AOC did not relate to time 2 LMXContribution $(B=.01, S E=.10, n s)$, controlling for its autoregressive effect $(B=.74, S E=.13, p<.001)$. These results provide support for the idea that LMX-Contribution temporally precedes AOC, which is consistent with the model presented in Fig. 2.
} 


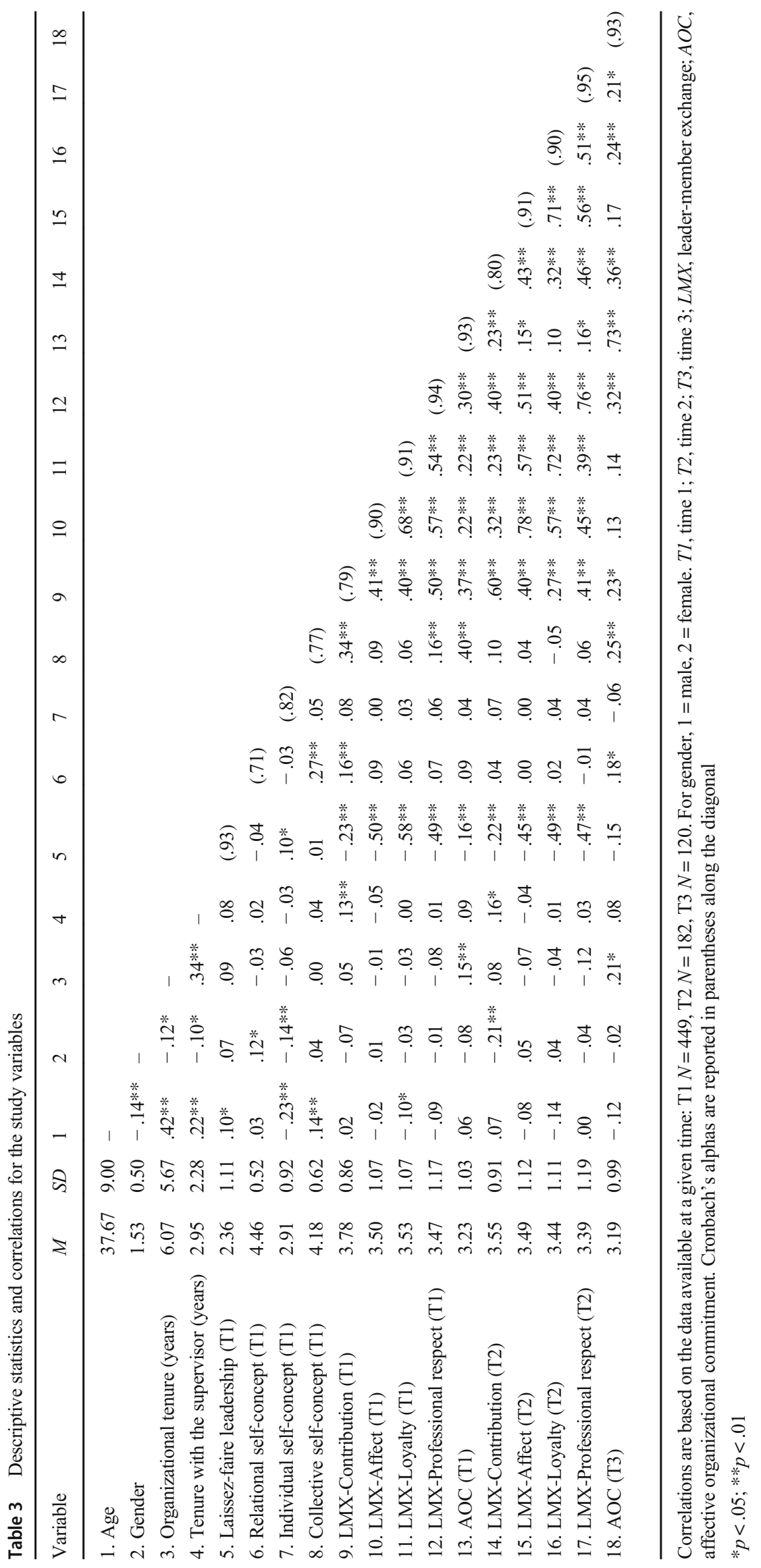


Table 4 Path analysis results for the moderation and moderated mediation models

\begin{tabular}{|c|c|c|c|c|c|c|c|c|c|}
\hline \multirow[b]{3}{*}{ Variable } & \multicolumn{4}{|c|}{ Moderation } & \multicolumn{5}{|c|}{ Moderated mediation } \\
\hline & \multicolumn{2}{|c|}{ Baseline model } & \multicolumn{2}{|c|}{ Moderated model } & \multicolumn{2}{|c|}{ Baseline model } & \multicolumn{3}{|c|}{ Moderated mediation model } \\
\hline & $B$ & $S E$ & $B$ & $S E$ & $B$ & $S E$ & $B$ & $S E$ & $95 \% \mathrm{CI}$ \\
\hline T1 Laissez-faire $\rightarrow$ T2 LMX-C & -.06 & .09 & -.04 & .08 & -.07 & .09 & -.05 & .08 & {$[-.209, .110]$} \\
\hline $\mathrm{T} 1 \mathrm{RSC} \rightarrow \mathrm{T} 2 \mathrm{LMX}-\mathrm{C}$ & .27 & .22 & .33 & .24 & .27 & .23 & .36 & .25 & {$[-.151, .885]$} \\
\hline $\mathrm{T} 1 \mathrm{CSC} \rightarrow \mathrm{T} 2 \mathrm{LMX}-\mathrm{C}$ & -.29 & .16 & -.31 & .16 & -.28 & .16 & -.31 & .17 & {$[-.646, .098]$} \\
\hline $\mathrm{T} 1 \mathrm{ISC} \rightarrow \mathrm{T} 2 \mathrm{LMX}-\mathrm{C}$ & -.01 & .12 & -.02 & .12 & -.00 & .12 & -.01 & .11 & {$[-.243, .219]$} \\
\hline T1 LMX-C $\rightarrow$ T2 LMX-C & $.73 * * *$ & .09 & $.74 * * *$ & .09 & $.73 * * *$ & .09 & $.74 * * *$ & .09 & {$[.571, .959]$} \\
\hline T1 Laissez-faire $\times$ T1 RSC $\rightarrow$ T2 LMX-C & & & $-.67 *$ & .28 & & & $-.69^{*}$ & .28 & {$[-1.317,-.174]$} \\
\hline T1 Laissez-faire $\rightarrow$ T3 AOC & & & & & -.09 & .07 & -.09 & .07 & {$[-.233, .041]$} \\
\hline $\mathrm{T} 1 \mathrm{RSC} \rightarrow \mathrm{T} 3 \mathrm{AOC}$ & & & & & $.51 *$ & .24 & $.57^{*}$ & .25 & {$[.046,1.122]$} \\
\hline $\mathrm{T} 1 \mathrm{CSC} \rightarrow \mathrm{T} 3 \mathrm{AOC}$ & & & & & -.22 & .13 & -.24 & .14 & {$[-.509, .106]$} \\
\hline $\mathrm{T} 1 \mathrm{ISC} \rightarrow \mathrm{T} 3 \mathrm{AOC}$ & & & & & -.12 & .09 & -.12 & .09 & {$[-.316, .061]$} \\
\hline $\mathrm{T} 1 \mathrm{AOC} \rightarrow \mathrm{T} 3 \mathrm{AOC}$ & & & & & $.72 * * *$ & .06 & $.72 * * *$ & .06 & {$[.595, .859]$} \\
\hline $\mathrm{T} 2 \mathrm{LMX}-\mathrm{C} \rightarrow \mathrm{T} 3 \mathrm{AOC}$ & & & & & $.15 * *$ & .05 & $.14 * *$ & .05 & {$[.023, .249]$} \\
\hline \multicolumn{10}{|l|}{ First stage moderation: } \\
\hline High RSC (+ $1 S D)$ & & & $-.34 *$ & .15 & & & $-.36^{*}$ & .15 & {$[-.672,-.067]$} \\
\hline Mean $(0)$ & & & -.04 & .08 & & & -.05 & .08 & {$[-.209, .110]$} \\
\hline Low RSC $(-1 S D)$ & & & .26 & .14 & & & .26 & .15 & {$[-.015, .595]$} \\
\hline Difference $( \pm 1 S D)$ & & & $-.60 *$ & .25 & & & $-.62 *$ & .25 & {$[-1.185,-.156]$} \\
\hline \multicolumn{10}{|l|}{ Indirect effect } \\
\hline High RSC (+ $1 S D)$ & & & & & & & $-.05^{*}$ & .03 & {$[-.111,-.002]$} \\
\hline Mean (0) & & & & & & & -.01 & .01 & {$[-.033, .017]$} \\
\hline Low RSC $(-1 S D)$ & & & & & & & .04 & .02 & {$[-.004, .098]$} \\
\hline Difference $( \pm 1 S D)$ & & & & & & & $-.09 *$ & .05 & {$[-.197,-.007]$} \\
\hline
\end{tabular}

$N=449$, based on full information maximum likelihood estimation. $B$, unstandardized beta coefficient; $S E$, standard error; $C I$, confidence interval; $T 1$, time 1; T2, time 2; T3, time 3; $L M X-C$, leader-member exchange, contribution dimension; $R S C$, relational self-concept; CSC, collective self-concept; $I S C$, individual self-concept; $A O C$, affective organizational commitment

$* p<.05 ; * * p<.01 ; * * * p<.001$

TLI $=.94$, RMSEA = .04; LMX-Professional respect: $\left.\chi^{2}(688)=1210.72, \mathrm{CFI}=.94, \mathrm{TLI}=.93, \mathrm{RMSEA}=.04\right)$. However, the moderated mediation model with time 2 LMX-Affect, LMX-Loyalty, and LMX-Professional respect as alternative mediators did not improve over the baseline model $(\mathrm{D}-2 \mathrm{LL}(1)=2.61, n s ; \mathrm{D}-2 \mathrm{LL}(1)=3.30, n s$; and $\mathrm{D}-2 \mathrm{LL}(1)=1.65, n s$; respectively). This finding indicates that the relational self-concept did not moderate the indirect relationship between laissez-faire leadership and time 3 AOC through the other dimensions of time 2 LMX.

Similarly, we examined whether the collective and individual self-concepts exerted a similar moderating effect in our mediation model. The baseline model (which was identical in both cases) displayed a good fit $\left(\chi^{2}(688)=1328.24\right.$, $\mathrm{CFI}=.92$, TLI $=.91$, RMSEA = .05). Unexpectedly, for both self-concept levels, we found that the moderated mediation model improved over the baseline model (D-2LL $(1)=5.75$, $p<.05$ (collective self-concept); and D-2LL(1) $=5.77, p<.05$ (individual self-concept)). In these models, the interaction between laissez-faire and the collective $(B=-.40, S E=.17$, $p<.05)$ and the individual $(B=-.29, S E=.13, p<.05)$ selfconcept were significant predictors of LMX-Contribution. The relationship between laissez-faire leadership and LMXContribution was significantly negative at high levels (i.e., 1 $S D$ above the mean) of the collective $(B=-.32, S E=.13$, $p<.05)$ and individual $(B=-.26, S E=.11, p<.05)$ selfconcept but nonsignificant at low levels (1 SD below the mean) of these moderators $(B=.19, S E=.15, n s$; and $B=.10, S E=.12, n s$; respectively). Differences between the two relationships were also significant for both the collective and the individual self-concept $(B=-.52, S E=.22, p<.05$; and $B=-.36, S E=.16, p<.05$, respectively).

Moreover, the indirect effect of laissez-faire leadership on AOC through LMX-Contribution was significantly negative $(B=-.05, S E=.02,95 \%$ CI $[-.113,-.006])$ when collective self-concept was high (1 $S D$ above the mean) but nonsignificant 


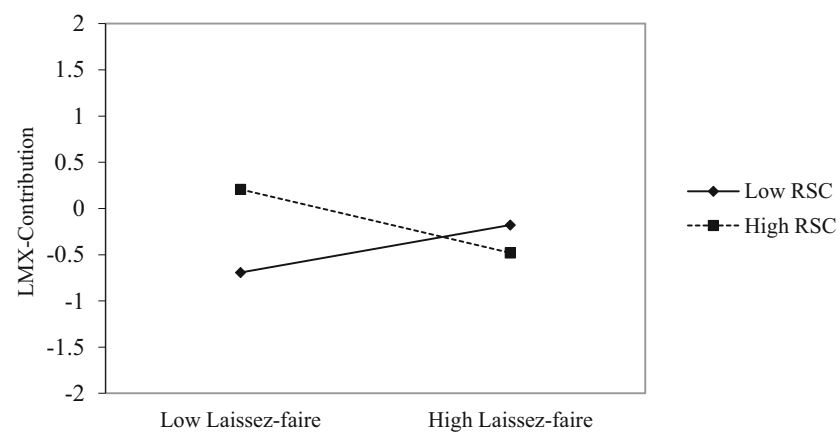

Fig. 1 Interaction between laissez-faire leadership and relational selfconcept (RSC) predicting LMX-Contribution. Relationships are shown at one $1 S D$ below and above the mean of RSC

$(B=.03, S E=.02,95 \% \mathrm{CI}[-.004, .108])$ when it was low $(1 S D$ below the mean); the difference between the two effects was significant $(B=-.08, S E=.04,95 \%$ CI $[-.208,-.013])$. In contrast, the indirect effect of laissez-faire leadership on AOC was nonsignificant at both high $(B=-.04, S E=.02,95 \%$ CI $[-.083$, $.000])$ and low $(B=.02, S E=.02,95 \%$ CI $[-.022, .055])$ levels of individual self-concept and did not differ across levels of this moderator $(B=-.05, S E=.03,95 \% \mathrm{CI}[-.116, .000])$. We elaborate on these results in the discussion.

\section{Discussion}

This study demonstrates that the relational self-concept acts as an important individual difference variable that affects the strength of the relationships among laissez-faire leadership, the LMX contribution dimension, and AOC. Using a threewave longitudinal study, these relationships were found to be stronger and negative among employees with strong relational self-concepts. As such, this study is a preliminary attempt to examine the mechanisms and boundary conditions that explain how laissez-faire leadership practices affect subordinates' reactions. Our conclusions are particularly robust given the use of a longitudinal approach that controlled for the baseline levels of the mediator and outcome variables. The next sections outline the implications of this study for our understanding of laissez-faire leadership.

\section{Theoretical Implications}

The overriding goal of the present study was foremost to address the theoretical gap surrounding the mechanisms and boundary conditions specifying when and how laissez-faire leadership is expected to relate to AOC. This research endeavor was timely given recent calls to increase our understanding of the effects of laissez-faire leadership (Bass \& Bass, 2008; Wong \& Giessner, 2018; Yang, 2015) and the need to account for subordinates' characteristics in examining these effects (Nielsen, Skogstad, Gjerstad, \& Einarsen, 2019). Building on the identity orientation framework (Brewer \& Gardner, 1996), we posited that a relational self-concept drives an employee's perception and evaluation of the appropriateness of laissez-faire leadership behaviors. Specifically, because dyadic relationships with significant others (e.g., supervisors) are an important part of an employee's self-definition, employees with strong relational self-concepts have high expectations about their leaders' behavior. Laissez-faire leadership violates these expectations, resulting in a reduced willingness of employees to contribute to the mutual goals associated with the relationship. As such, this study furthers our knowledge of the role of employees' characteristics, which are usually neglected in studies about negative leadership (Schyns \& Schilling, 2013). It also contributes to a growing body of literature that has highlighted the role of the employee self-concept as an important trait-like variable to consider in work settings (e.g., van Knippenberg et al., 2004).

The present results are consistent with the view that, even if laissez-faire leadership is a form of passive leadership, it can have destructive effects (e.g., Skogstad et al., 2007) because it can damage the employee-supervisor relationship and

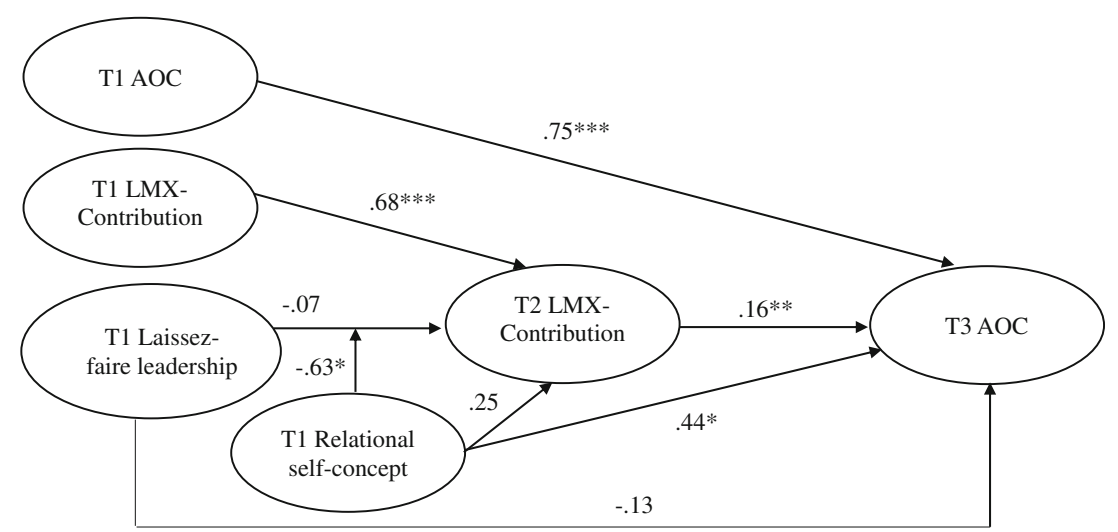

Fig. 2 Standardized parameter estimates for the moderated mediation model. T1, time 1; T2, time 2; T3, t3; LMX, leader-member exchange; AOC, affective organizational commitment. For the sake of parsimony, control variables (i.e., individual and collective self-concepts) are omitted (their effects are reported in Table 4). Correlations among exogenous variables are not shown. $* p<.05 ; * * p<.01 ; * * * p<.001$ 
organizational commitment, at least when employees have strong relational self-concepts. This view extends the LMX literature, which has traditionally focused on the outcomes rather than on the predictors of LMX (Erdogan \& Liden, 2002; Yukl, O’Donnell, \& Taber, 2009). Furthermore, our results demonstrate that different styles of leadership may foster different aspects of LMX (e.g., Lee, 2005) and provide further support to the benefits of considering a disaggregated approach to the study of LMX. Moreover, previous research has mostly investigated leadership antecedents that may foster LMX, such as transformational leadership (e.g., Wang, Law, Hackett, Wang, \& Chen, 2005), neglecting those leadership styles that act as negative antecedents of LMX. The present results suggest that LMX is affected by negative forms of leadership, which should encourage researchers to examine negative reciprocity as a specific mechanism accounting for the sensitivity of LMX to negative leadership.

Nonetheless, the present findings suggest that the negative effects of laissez-faire leadership are not universal. Rather, these effects particularly occur when employees hold strong relational self-concepts. As such, the relational self-concept is particularly important to explain the impact of laissez-faire leadership on AOC, possibly because individuals with relational self-concepts are more inclined to direct their affective reactions toward their exchange partners (Flynn, 2005), which are then generalized to the organization. Consequently, it appears important to consider the intraindividual context of laissez-faire leadership. Our results also echo Johnson and Chang's (2008) proposition that individual differences may calibrate employees' relative sensitivity to the antecedents of AOC. The present findings indicate that employees with low relational self-concepts do not reduce their contribution to mutual goals when they are exposed to laissez-faire leadership. They may even increase this contribution when they hold very low relational self-concepts. Thus, laissez-faire leadership cannot be said to be universally detrimental to employees' relationship with supervisors and attachment to the organization. This observation goes against the literature that has concluded to consistent negative effects of laissez-faire leadership across situations and contexts (e.g., Bass \& Bass, 2008).

As self-concepts and their associated needs shape the perception and interpretation of what constitutes appropriate leader behavior, it is actually the congruence between leader behavior and employees' expectations and needs that would drive employee reactions (e.g., Wong \& Giessner, 2018). Thus, leaders need to adjust their behavior to followers' characteristics, an argument set forth by the theories of situational or contingent leadership (Fiedler, 2006; Vroom \& Jago, 2007; Yukl, 2010). By extension, one may think that followers differ in their needs for leadership and that it is the nonresponse to employees' specific needs that has the largest influence (de Vries, Roe, \& Taillieu, 2002). In sum, this study provides a preliminary answer to Bass and Bass's (2008, p. 1193) call for addressing the question of "when is laissez-faire leadership appropriate and effective?"

\section{Directions for Future Research}

Unexpectedly, all three levels of the self-concept were found to enhance the impact of laissez-faire leadership. Therefore, in addition to the relational expectations associated with the relational self-concept, other mechanisms may come into play. One potential mechanism is that individuals may be sensitive to any threat to their self-definitions and the accomplishment of the goals they are striving for (e.g., Leavitt \& Sluss, 2015). Laissez-faire leaders would have negative effects because they would fall short of meeting the expectations and goals associated with all three self-concept levels. We speculate that when any level of the self-concept is high, a feeling of identity threat will emerge from exposure to laissez-faire leadership. For example, as employees with strong individual self-concepts are committed to achieve career goals (Johnson, Chang, \& Yang, 2010), they may be frustrated by laissez-faire leaders because they do not take actions that facilitate their career progress. Similarly, employees with strong collective self-concepts take the well-being of their workgroup to heart (Johnson et al., 2010) and may thus be disappointed to see laissez-faire leaders not working at building cohesion within their workgroup, which would threaten their identities as members of the group. This may reduce their contributions to mutual goals and ultimately AOC. In line with these avenues for future inquiry, past research has suggested that the same leadership style may influence multiple identity-related processes among employees (e.g., Wu et al., 2010). Future research is needed to examine how laissez-faire leadership can threaten the achievement of the goals associated with each of the selfconcept levels.

Another avenue for future research would be to examine why leaders engage in laissez-faire behaviors. Do they simply engage in laissez-faire behaviors unknowingly or because they do not have the desire, the knowledge, or the resources to fulfill their prescribed role? Courtright, Colbert, and Choi (2014) suggested that leaders may engage in such behaviors due to developmental challenges and emotional exhaustion. Studying the antecedents of and potential explanations for such behaviors would increase our knowledge regarding when laissez-faire leadership behaviors emerge in the workplace, hence contributing to leadership development (Day, Fleenor, Atwater, Sturm, \& McKee, 2014). While these reasons may differ across leaders, identifying those factors that foster laissez-faire practices would help work against its potentially harmful effects and implement interventions that limit their occurrence. For example, examining leaders' own selfconcept levels would be worthwhile (van Knippenberg et al., 2004). Speculatively, leaders with strong individual self- 
concepts may be more focused on their own ambitions and personal goals, thus neglecting employees' needs, which may pave the way for laissez-faire behaviors. These leaders may want to move up the corporate ladder and think that a management position is a step toward this goal, even in the absence of a personal desire to supervise employees. Previous research has associated the individual self-concept with more frequent abusive behaviors (Johnson, Venus, Lanaj, Mao, \& Chang, 2012). This logic could be extended to laissez-faire leadership, with stronger individual self-concepts making leaders more prone to engage in laissez-faire behaviors.

More generally, laissez-faire leadership remains an understudied form of leadership. One area where more work is needed concerns the similarities and differences between laissezfaire leadership and other destructive forms of leadership. In a recent meta-analysis of destructive leadership in military contexts, Fosse, Skogstad, Einarsen, and Martinussen (2019) found that active-destructive leadership (e.g., abusive supervision, supervisor undermining) and passive-destructive leadership (e.g., laissez-faire) had similar negative relationships with job performance, job attitudes, and employee health and well-being. However, as LMX was not included in the outcomes addressed in this meta-analytic review, it remains unclear how the different forms of destructive leadership distinctively contribute to undermine LMX development and whether some LMX dimensions are particularly affected by them. Future research should thus attempt to disentangle the effects of the different forms of destructive leadership on LMX development.

\section{Practical Implications}

Organizations should train leaders to detect, reduce, and understand the implications of laissez-faire behaviors, just as they do for positive leadership practices. This approach would help practitioners to know not only when to act but also when not to act. Practitioners should be aware that appropriate actions may not only depend on situations per se but on an employee's specific needs as well. Discrepancies between the leader's behaviors and the employee's expectations or specific needs may explain the relative impact of laissezfaire leadership. Therefore, interventions implemented to increase the quality of relationships between employees and leaders and to foster organizational commitment must be adapted based on employees' levels of the self-concept because these levels drive their expectations. As our research has shown, even individuals who tend to focus on contributing to others' well-being (i.e., with a strong relational selfconcept; Brewer \& Gardner, 1996) are still capable of developing attitudes and behaviors that go against their natural tendencies. Thus, laissez-faire leadership may result in the relational potential of employees being wasted because it promotes inappropriate behaviors. Practitioners should take the time to get to know their employees' needs and self-concepts, communicate on these aspects, and strive to fulfill employees' expectations. Hence, organizations should pay greater attention to the diversity of employees' characteristics to fully realize the potential of their employees. Recognizing the diversity of identity-related expectations should be reflected in programs and practices, such as recruitment and socialization processes (Ashforth \& Schinoff, 2016), that are tied to employees' self-concept orientations (Pratt, 2000). By taking advantage of these diverse opportunities, organizations could build stronger bonds and hope for better performance and increased retention among employees.

\section{Limitations}

As study measures were self-reported, common method bias may be an issue (Podsakoff, MacKenzie, \& Podsakoff, 2012). Nonetheless, self-reports might be appropriate given our focus on perceptions of self-identity levels and attitudes in the workplace (Conway \& Lance, 2010; Spector, 2006). Previous research on the self-concept has indeed traditionally relied on self-report measures (Byrne, 2002). Moreover, our longitudinal analysis controlled for the baseline levels of both the mediator (i.e., LMX-Contribution) and outcome (i.e., AOC) variables, thus considerably reducing any endogeneity related to our findings (Podsakoff, MacKenzie, Lee, \& Podsakoff, 2003) and lending confidence to their robustness. Furthermore, because our hypotheses focused on the interaction between laissez-faire leadership and the relational selfconcept, common method variance is unlikely to have affected the findings (Siemsen, Roth, \& Oliveira, 2010). We also recognize that this study used a specific sample of highly educated employees from a culturally individualistic context. It is possible that different results would be found in a collectivistic culture, as self-concepts are known to be developed in relation to the social context and to vary across cultures (Oyserman, 2001). Hence, people from a Western culture would have stronger individual self-concepts, while those from Eastern countries would possess stronger collective identities (Kitayama, Markus, Matsumoto, \& Norasakkunkit, 1997). Nonetheless, even if some findings seem to support a universalist perspective of the self (Sedikides et al., 2011), future research is needed to further examine the generalizability of our findings. Finally, we used the LMX-MDM measure (Liden \& Maslyn, 1998) to capture the social exchangebased relationship between employees and leaders. However, this instrument has been criticized for providing an imperfect assessment of social exchange, leading to the development of leader-member social exchange (LMSX) as an alternative measure of the construct (Bernerth, Armenakis, Feild, Giles, \& Walker, 2007). It would be worth exploring whether the current findings could be replicated using this alternative measure of social exchange relationships in employee-supervisor dyads. 


\section{Conclusion}

The present study indicates that laissez-faire leadership negatively relates to AOC through decreased levels of the LMX contribution dimension but only when the employee's relational self-concept is high. As such, this study highlights how relational expectations can strengthen the (negative) impact of laissez-faire leadership and reveals that it is through employees' reduced contribution to mutual goals that AOC comes to be affected by laissez-faire leadership. We hope the present study will encourage future attempts at exploring the conditions and mechanisms associated with the effects of laissez-faire leadership in organizations.

Open Access This article is licensed under a Creative Commons Attribution 4.0 International License, which permits use, sharing, adaptation, distribution and reproduction in any medium or format, as long as you give appropriate credit to the original author(s) and the source, provide a link to the Creative Commons licence, and indicate if changes were made. The images or other third party material in this article are included in the article's Creative Commons licence, unless indicated otherwise in a credit line to the material. If material is not included in the article's Creative Commons licence and your intended use is not permitted by statutory regulation or exceeds the permitted use, you will need to obtain permission directly from the copyright holder. To view a copy of this licence, visit http://creativecommons.org/licenses/by/4.0/.

\section{References}

Aasland, M. S., Skogstad, A., Notelaers, G., Nielsen, M. B., \& Einarsen, S. (2010). The prevalence of destructive leadership behaviour. British Journal of Management, 21, 438-452. https://doi.org/10. 1111/j.1467-8551.2009.00672.x.

Allen, N. J., \& Meyer, J. P. (1990). The measurement and antecedents of affective, continuance and normative commitment to the organization. Journal of Occupational Psychology, 63, 1-8. https://doi.org/ 10.1111/j.2044-8325.1990.tb00506.x.

Andersen, S. M., \& Chen, S. (2002). The relational self: An interpersonal social-cognitive theory. Psychological Review, 109, 619-645. https://doi.org/10.1037/0033-295X.109.4.619.

Aryee, S., Chen, Z. X., Sun, L. Y., \& Debrah, Y. A. (2007). Antecedents and outcomes of abusive supervision: Test of a trickle-down model. Journal of Applied Psychology, 92, 191-201. https://doi.org/10. 1037/0021-9010.92.1.191.

Ashforth, B. E., \& Schinoff, B. S. (2016). Identity under construction: How individuals come to define themselves in organizations. Annual Review of Organizational Psychology and Organizational Behavior, 3, 111-137. https://doi.org/10.1146/annurev-orgpsych041015-062322.

Avolio, B. J. (2011). Full range leadership development (2nd ed.). Thousand Oaks, CA: Sage Publications. https://doi.org/10.4135/ 9781483349107.

Bass, B. M. (1998). Transformational leadership: Industrial military, and educational impact. Mahwah, NJ: Lawrence Erlbaum Associates.

Bass, B. M., \& Avolio, B. J. (1991). Multifactor leadership questionnaire (form $5 X$ ). Center for Leadership Studies: School of Management, Binghamton University.
Bass, B. M., \& Bass, R. (2008). The Bass handbook of leadership: Theory, research, and managerial applications (4th ed.). New York: Free Press.

Bass, B. M., \& Stogdill, R. M. (1990). Bass \& Stogdill's handbook of leadership: Theory, research, and managerial applications (3rd ed.). New York: Simon and Schuster.

Baumeister, R. F., Bratslavsky, E., Finkenauer, C., \& Vohs, K. D. (2001). $\mathrm{Bad}$ is stronger than good. Review of General Psychology, 5, 323370. https://doi.org/10.1037//1089-2680.5.4.323.

Bentein, K., Vandenberg, R. J., Vandenberghe, C., \& Stinglhamber, F. (2005). The role of change in the relationship between commitment and turnover: A latent growth modeling approach. Journal of Applied Psychology, 90, 468-482. https://doi.org/10.1037/00219010.90.3.468.

Bentler, P. M., \& Bonett, D. G. (1980). Significance tests and goodness of fit in the analysis of covariance structures. Psychological Bulletin, 88, 588-606. https://doi.org/10.1037/0033-2909.88.3.588.

Bernerth, J. B., Armenakis, A. A., Feild, H. S., Giles, W. F., \& Walker, H. J. (2007). Leader-member social exchange (LMSX): Development and validation of a scale. Journal of Organizational Behavior, 28, 979-1003. https://doi.org/10.1002/job.443.

Blau, P. M. (1964). Exchange and power in social life. New York: John Wiley \& Sons.

Boies, K., \& Howell, J. M. (2006). Leader-member exchange in teams: An examination of the interaction between relationship differentiation and mean LMX in explaining team-level outcomes. The Leadership Quarterly, 17, 246-257. https://doi.org/10.1016/j. leaqua.2006.02.004.

Brewer, M. B., \& Chen, Y.-R. (2007). Where (who) are collectives in collectivism? Toward conceptual clarification of individualism and collectivism. Psychological Review, 114, 133-151. https://doi.org/ 10.1037/0033-295X.114.1.133.

Brewer, M. B., \& Gardner, W. (1996). Who is this "We"? Levels of collective identity and self representations. Journal of Personality and Social Psychology, 71, 83-93. https://doi.org/10.1037/00223514.71.1.83.

Brickson, S. (2000). The impact of identity orientation on individual and organizational outcomes in demographically diverse settings. Academy of Management Review, 25, 82-101. https://doi.org/10. 2307/259264.

Buch, R., Martinsen, Ø. L., \& Kuvaas, B. (2015). The destructiveness of laissez-faire leadership behavior: The mediating role of economic leader-member exchange relationships. Journal of Leadership \& Organizational Studies, 22, 115-124. https://doi.org/10.1177/ 1548051813515302.

Byrne, B. M. (2002). Validating the measurement and structure of selfconcept: Snapshots of past, present, and future research. American Psychologist, 57, 897-909. https://doi.org/10.1037/0003-066X.57. 11.897.

Byrne, B. M., Shavelson, R. J., \& Muthén, B. (1989). Testing for the equivalence of factor covariance and mean structures: The issue of partial measurement invariance. Psychological Bulletin, 105, 456466. https://doi.org/10.1037/0033-2909.105.3.456.

Chang, C.-H., \& Johnson, R. E. (2010). Not all leader-member exchanges are created equal: Importance of leader relational identity. The Leadership Quarterly, 21, 796-808. https://doi.org/10.1016/j. leaqua.2010.07.008.

Che, X. X., Zhou, Z. E., Kessler, S. R., \& Spector, P. E. (2017). Stressors beget stressors: The effect of passive leadership on employee health through workload and work-family conflict. Work \& Stress, 31, 338-354. https://doi.org/10.1080/02678373.2017.1317881.

Chen, X. P., He, W., \& Weng, L. C. (2018). What is wrong with treating followers differently? The basis of leader-member exchange differentiation matters. Journal of Management, 44, 946-971. https://doi. org/10.1177/0149206315598372. 
Cheung, G. W., \& Lau, R. S. (2012). A direct comparison approach for testing measurement invariance. Organizational Research Methods, 15, 167-198. https://doi.org/10.1177/1094428111421987.

Cheung, G. W., \& Lau, R. S. (2017). Accuracy of parameter estimates and confidence intervals in moderated mediation models: A comparison of regression and latent moderated structural equations. Organizational Research Methods, 20, 746-769. https://doi.org/ $10.1177 / 1094428115595869$.

Cole, D. A., \& Maxwell, S. E. (2003). Testing mediational models with longitudinal data: Questions and tips in the use of structural equation modeling. Journal of Abnormal Psychology, 112, 558-577. https:// doi.org/10.1037/0021-843X.112.4.558.

Conway, J. M., \& Lance, C. E. (2010). What reviewers should expect from authors regarding common method bias in organizational research. Journal of Business and Psychology, 25, 325-334. https:// doi.org/10.1007/s10869-010-9181-6.

Courtright, S. H., Colbert, A. E., \& Choi, D. (2014). Fired up or burned out? How developmental challenge differentially impacts leader behavior. Journal of Applied Psychology, 99, 681-696. https://doi.org/ 10.1037/a0035790.

Dansereau Jr., F., Graen, G., \& Haga, W. J. (1975). A vertical dyad linkage approach to leadership within formal organizations: A longitudinal investigation of the role making process. Organizational Behavior and Human Performance, 13, 46-78. https://doi.org/10. 1016/0030-5073(75)90005-7.

Day, D. V., Fleenor, J. W., Atwater, L. E., Sturm, R. E., \& McKee, R. A. (2014). Advances in leader and leadership development: A review of 25 years of research and theory. The Leadership Quarterly, 25, 63-82. https://doi.org/10.1016/j.leaqua.2013.11.004.

De Cremer, D. (2003). A relational perspective on leadership and cooperation: Why it matters to care and be fair. In D. van Knippenberg \& M. A. Hogg (Eds.), Leadership and power: Identity processes in groups and organizations (pp. 109-122). London, UK: Sage Publications. https://doi.org/10.4135/9781446216170.n9.

de Vries, R. E., Roe, R. A., \& Taillieu, T. C. (2002). Need for leadership as a moderator of the relationships between leadership and individual outcomes. The Leadership Quarterly, 13, 121-137. https://doi. org/10.1016/S1048-9843(02)00097-8.

Den Hartog, D. N., Van Muijen, J. J., \& Koopman, P. L. (1997). Transactional versus transformational leadership: An analysis of the MLQ. Journal of Occupational and Organizational Psychology, 70, 19-34. https://doi.org/10.1111/j.2044-8325.1997. tb00628.x.

Dienesch, R. M., \& Liden, R. C. (1986). Leader-member exchange model of leadership: A critique and further development. Academy of Management Review, 11, 618-634. https://doi.org/10.5465/amr. 1986.4306242.

Dimitruk, P., Schermelleh-Engel, K., Kelava, A., \& Moosbrugger, H. (2007). Challenges in nonlinear structural equation modeling. Methodology, 3, 100-114. https://doi.org/10.1027/1614-2241.3.3.100.

Dulebohn, J. H., Bommer, W. H., Liden, R. C., Brouer, R. L., \& Ferris, G. R. (2012). A meta-analysis of antecedents and consequences of leader-member exchange: Integrating the past with an eye toward the future. Journal of Management, 38, 1715-1759. https://doi.org/ $10.1177 / 0149206311415280$.

Dulebohn, J. H., Wu, D., \& Liao, C. (2017). Does liking explain variance above and beyond LMX? A meta-analysis. Human Resource Management Review, 27, 149-166. https://doi.org/10.1016/j.hrmr. 2016.09.008

Dumdum, U. R., Lowe, K. B., \& Avolio, B. J. (2002). A meta-analysis of transformational and transactional leadership correlates of effectiveness and satisfaction: An update and extension. In B. J. Avolio \& F. J. Yammarino (Eds.), Transformational and charismatic leadership: The road ahead (pp. 35-66). Oxford, UK: Elsevier Science.

Eagly, A. H., Johannesen-Schmidt, M. C., \& van Engen, M. L. (2003). Transformational, transactional, and laissez-faire leadership styles: A meta-analysis comparing women and men. Psychological Bulletin, 129, 569-591. https://doi.org/10.1037/0033-2909.129.4.569.

Einarsen, S., Aasland, M. S., \& Skogstad, A. (2007). Destructive leadership behavior: A definition and conceptual model. The Leadership Quarterly, 18, 207-216. https://doi.org/10.1016/j.leaqua.2007.03.002.

Eisenberger, R., Aselage, J., Sucharski, I. L., \& Jones, J. R. (2004). Perceived organizational support. In J. Coyle-Shapiro, L. Shore, S. Taylor, \& L. Tetrick (Eds.), The employment relationship: Examining psychological and contextual perspectives (pp. 207225). New York: Oxford University Press.

Eisenberger, R., Karagonlar, G., Stinglhamber, F., Neves, P., Becker, T. E., Gonzalez-Morales, M. G., \& Steiger-Mueller, M. (2010). Leader-member exchange and affective organizational commitment: The contribution of supervisor's organizational embodiment. Journal of Applied Psychology, 95, 1085-1103. https://doi.org/10. 1037/a0020858.

Eisenberger, R., Stinglhamber, F., Vandenberghe, C., Sucharski, I. L., \& Rhoades, L. (2002). Perceived supervisor support: Contributions to perceived organizational support and employee retention. Journal of Applied Psychology, 87, 565-573. https://doi.org/10.1037/00219010.87.3.565.

Enders, C. K. (2010). Applied missing data analysis. New York: Guilford Press.

Epitropaki, O., Kark, R., Mainemelis, C., \& Lord, R. G. (2017). Leadership and followership identity processes: A multilevel review. The Leadership Quarterly, 28, 104-129. https://doi.org/10. 1016/j.leaqua.2016.10.003.

Erdogan, B., \& Bauer, T. N. (2010). Differentiated leader-member exchanges: The buffering role of justice climate. Journal of Applied Psychology, 95, 1104-1120. https://doi.org/10.1037/a0020578.

Erdogan, B., \& Liden, R. C. (2002). Social exchanges in the workplace: A review of recent developments and future research directions in leader-member exchange theory. In L. L. Neider \& C. A. Schriesheim (Eds.), Leadership (pp. 65-114). Greenwich, CT: Information Age Publishing.

Ferris, D. L., Yan, M., Lim, V. K., Chen, Y., \& Fatimah, S. (2016). An approach-avoidance framework of workplace aggression. Academy of Management Journal, 59, 1777-1800. https://doi.org/10.5465/ amj.2014.0221.

Fiedler, F. E. (2006). The contingency model: A theory of leadership effectiveness. In J. M. Levine \& R. L. Moreland (Eds.), Small groups: Key readings (pp. 369-381). New York: Psychology Press.

Fitzmaurice, G. M., Laird, N. M., \& Ware, J. H. (2004). Applied longitudinal analysis. Hoboken, NJ: Wiley-Interscience.

Flynn, F. J. (2005). Identity orientations and forms of social exchange in organizations. Academy of Management Review, 30, 737-750. https://doi.org/10.2307/20159165.

Fosse, T. H., Skogstad, A., Einarsen, S. V., \& Martinussen, M. (2019). Active and passive forms of destructive leadership in a military context: A systematic review and meta-analysis. European Journal of Work and Organizational Psychology, 28, 708-722. https://doi.org/10.1080/1359432X.2019.1634550.

Gaertner, L., Sedikides, C., Luke, M., O’Mara, E. M., Iuzzini, J., Jackson, L. E., Cai, H., \& Wu, Q. (2012). A motivational hierarchy within: Primacy of the individual self, relational self, or collective self? Journal of Experimental Social Psychology, 48, 997-1013. https:// doi.org/10.1016/j.jesp.2012.03.009.

Geiser, C. (2012). Data analysis with Mplus. New York: Guilford Press.

Gerstner, C. R., \& Day, D. V. (1997). Meta-analytic review of leadermember exchange theory: Correlates and construct issues. Journal of Applied Psychology, 82, 827-844. https://doi.org/10.1037/00219010.82.6.827.

Goodman, J. S., \& Blum, T. C. (1996). Assessing the non-random sampling effects of subject attrition in longitudinal research. Journal of Management, 22, 627-652. https://doi.org/10.1177/ 014920639602200405 . 
Graen, G. B., \& Cashman, J. F. (1975). A role making model of leadership in formal organizations: A developmental approach. In J. G. Hunt \& L. L. Larson (Eds.), Leadership frontiers (pp. 143-165). Kent, OH: Kent State University Press.

Graen, G. B., \& Scandura, T. A. (1987). Toward a psychology of dyadic organizing. Research in Organizational Behavior, 9, 175-208.

Graham, J. W. (2009). Missing data analysis: Making it work in the real world. Annual Review of Psychology, 60, 549-576. https://doi.org/ 10.1146/annurev.psych.58.110405.085530.

Graham, J. W. (2012). Missing data: Analysis and design. New York, NY: Springer.

Greguras, G. J., \& Ford, J. M. (2006). An examination of the multidimensionality of supervisor and subordinate perceptions of leadermember exchange. Journal of Occupational and Organizational Psychology, 79, 433-465. https://doi.org/10.1348/ $096317905 X 53859$.

Henderson, D., Liden, R., Glibkowski, B., \& Chaudhry, A. (2009). LMX differentiation: A multilevel review and examination of its antecedents and outcomes. The Leadership Quarterly, 20, 517-534. https:// doi.org/10.1016/j.leaqua.2009.04.003.

Herdman, A. O., Yang, J., \& Arthur, J. B. (2017). How does leadermember exchange disparity affect teamwork behavior and effectiveness in work groups? The moderating role of leader-leader exchange. Journal of Management, 43, 1498-1523. https://doi.org/ $10.1177 / 0149206314556315$.

Hinkin, T. R., \& Schriesheim, C. A. (2008a). An examination of "nonleadership": From laissez-faire leadership to leader reward omission and punishment omission. Journal of Applied Psychology, 93, 1234-1248. https://doi.org/10.1037/a0012875.

Hinkin, T. R., \& Schriesheim, C. A. (2008b). A theoretical and empirical examination of the transactional and non-leadership dimensions of the Multifactor Leadership Questionnaire (MLQ). The Leadership Quarterly, 19, 501-513. https://doi.org/10.1016/j.leaqua.2008.07.001.

Hogg, M. A. (2001). A social identity theory of leadership. Personality and Social Psychology Review, 5, 184-200. https://doi.org/10.1207/ S15327957PSPR0503 1.

Hogg, M. A., Martin, R., \& Weeden, K. (2003). Leader-member relations and social identity. In D. van Knippenberg \& M. A. Hogg (Eds.), Leadership and power: Identity processes in groups and organizations (pp. 18-33). London, UK: Sage Publications. https://doi.org/10.4135/9781446216170.n3.

Hogg, M. A., \& van Knippenberg, D. (2003). Social identity and leadership processes in groups. In M. P. Zanna (Ed.), Advances in experimental social psychology (Vol. 35, pp. 1-52). San Diego, CA: Elsevier Academic Press. https://doi.org/10.1016/S0065-2601(03)01001-3.

Jackson, E. M., \& Johnson, R. E. (2012). When opposites do (and do not) attract: Interplay of leader and follower self-identities and its consequences for leader-member exchange. The Leadership Quarterly, 23, 488-501. https://doi.org/10.1016/j.leaqua.2011.12.003.

Johnson, R. E., \& Chang, C. H. (2008). Relationships between organizational commitment and its antecedents: Employee self-concept matters. Journal of Applied Social Psychology, 38, 513-541. https://doi. org/10.1111/j.1559-1816.2008.00315.x.

Johnson, R. E., Chang, C.-H., \& Yang, L.-Q. (2010). Commitment and motivation at work: The relevance of employee identity and regulatory focus. Academy of Management Review, 35, 226-245. https:// doi.org/10.5465/amr.35.2.zok226.

Johnson, R. E., \& Saboe, K. N. (2011). Measuring implicit traits in organizational research: Development of an indirect measure of employee implicit self-concept. Organizational Research Methods, 14, 530-547. https://doi.org/10.1177/1094428110363617.

Johnson, R. E., Selenta, C., \& Lord, R. G. (2006). When organizational justice and the self-concept meet: Consequences for the organization and its members. Organizational Behavior and Human Decision Processes, 99, 175-201. https://doi.org/10.1016/j.obhdp.2005.07.005.
Johnson, R. E., Venus, M., Lanaj, K., Mao, C., \& Chang, C.-H. (2012). Leader identity as an antecedent of the frequency and consistency of transformational, consideration, and abusive leadership behaviors. Journal of Applied Psychology, 97, 1262-1272. https://doi.org/10. 1037/a0029043.

Judge, T. A., \& Piccolo, R. F. (2004). Transformational and transactional leadership: A meta-analytic test of their relative validity. Journal of Applied Psychology, 89, 755-768. https://doi.org/10.1037/00219010.89.5.755.

Kashima, E. S., \& Hardie, E. A. (2000). The development and validation of the relational, individual, and collective self-aspects (RIC) scale. Asian Journal of Social Psychology, 3, 19-48. https://doi.org/10. 1111/1467-839X.00053.

Kelloway, E. K., Mullen, J., \& Francis, L. (2006). Divergent effects of transformational and passive leadership on employee safety. Journal of Occupational Health Psychology, 11, 76-86. https:// doi.org/10.1037/1076-8998.11.1.76.

Kelloway, E. K., Sivanathan, N., Francis, L., \& Barling, J. (2005). Poor leadership. In J. Barling, E. K. Kelloway, \& M. R. Frone (Eds.), Handbook of work stress (pp. 89-112). London, UK: SAGE Publications. https://doi.org/10.4135/9781412975995.n5.

Kitayama, S., Markus, H. R., Matsumoto, H., \& Norasakkunkit, V. (1997). Individual and collective processes in the construction of the self: Self-enhancement in the United States and self-criticism in Japan. Journal of Personality and Social Psychology, 72, 12451267. https://doi.org/10.1037//0022-3514.72.6.1245.

Klein, A., \& Moosbrugger, H. (2000). Maximum likelihood estimation of latent interaction effects with the LMS method. Psychometrika, 65 , 457-474. https://doi.org/10.1007/BF02296338.

Kuvaas, B., Buch, R., Dysvik, A., \& Haerem, T. (2012). Economic and social leader-member exchange relationships and follower performance. The Leadership Quarterly, 23, 756-765. https://doi.org/10. 1016/j.leaqua.2011.12.013.

Lavelle, J. J., Rupp, D. E., \& Brockner, J. (2007). Taking a multifoci approach to the study of justice, social exchange, and citizenship behavior: The target similarity model. Journal of Management, 33, 841-866. https://doi.org/10.1177/0149206307307635.

Law, K. S., Wang, H., \& Hui, C. (2010). Currencies of exchange and global LMX: How they affect employee task performance and extrarole performance. Asia Pacific Journal of Management, 27, 625646. https://doi.org/10.1007/s10490-009-9141-8.

Le Blanc, P. M., \& González-Romá, V. (2012). A team level investigation of the relationship between leader-member exchange (LMX) differentiation, and commitment and performance. The Leadership Quarterly, 23, 534-544. https://doi.org/10.1016/j.leaqua.2011.12.006.

Leavitt, K., \& Sluss, D. M. (2015). Lying for who we are: An identitybased model of workplace dishonesty. Academy of Management Review, 40, 587-610. https://doi.org/10.5465/amr.2013.0167.

Lee, J. (2005). Effects of leadership and leader-member exchange on commitment. Leadership \& Organization Development Journal, 26, 655-672. https://doi.org/10.1108/01437730510633728.

Liden, R. C., Erdogan, B., Wayne, S. J., \& Sparrowe, R. T. (2006). Leadermember exchange, differentiation, and task interdependence: Implications for individual and group performance. Journal of Organizational Behavior, 27, 1-24. https://doi.org/10.1002/job.409.

Liden, R. C., \& Graen, G. (1980). Generalizability of the vertical dyad linkage model of leadership. Academy of Management Journal, 23, 451-465. https://doi.org/10.2307/255511.

Liden, R. C., \& Maslyn, J. M. (1998). Multidimensionality of leadermember exchange: An empirical assessment through scale development. Journal of Management, 24, 43-72. https://doi.org/10.1016/ S0149-2063(99)80053-1.

Liden, R. C., Wayne, S. J., \& Sparrowe, R. T. (2000). An examination of the mediating role of psychological empowerment on the relations between the job, interpersonal relationships, and work outcomes. 
Journal of Applied Psychology, 85, 407-416. https://doi.org/10. 1037/0021-9010.85.3.407.

Little, T. D. (2013). Longitudinal structural equation modeling. New York: Guilford Press.

Lord, R. G., \& Brown, D. J. (2001). Leadership, values, and subordinate self-concepts. The Leadership Quarterly, 12, 133-152. https://doi. org/10.1016/S1048-9843(01)00072-8.

Lord, R. G., \& Brown, D. J. (2004). Leadership processes and follower self-identity. Mahwah, NJ: Lawrence Erlbaum Associates Publishers.

Lord, R. G., Brown, D. J., \& Freiberg, S. J. (1999). Understanding the dynamics of leadership: The role of follower self-concepts in the leader/follower relationship. Organizational Behavior and Human Decision Processes, 78, 167-203. https://doi.org/10.1006/obhd. 1999.2832

Lowe, K. B., Kroeck, K. G., \& Sivasubramaniam, N. (1996). Effectiveness correlates of transformational and transactional leadership: A meta-analytic review of the MLQ literature. The Leadership Quarterly, 7, 385-425. https://doi.org/10.1016/S10489843(96)90027-2.

MacKinnon, D. P., Lockwood, C. M., \& Williams, J. (2004). Confidence limits for the indirect effect: Distribution of the product and resampling methods. Multivariate Behavioral Research, 39, 99-128. https://doi.org/10.1207/s15327906mbr3901_4.

Markus, H., \& Wurf, E. (1987). The dynamic self-concept: A social psychological perspective. Annual Review of Psychology, 38, 299 337. https://doi.org/10.1146/annurev.ps.38.020187.001503.

Marsh, H. W., Abduljabbar, A. S., Abu-Hilal, M. M., Morin, A. J. S., Abdelfattah, F., Leung, K. C., Xu, M. K., Nagengast, B., \& Parker, P. (2013). Factorial, convergent, and discriminant validity of TIMSS math and science motivation measures: A comparison of Arab and Anglo-Saxion countries. Journal of Educational Psychology, 105, 108-128. https://doi.org/10.1037/a0029907.

Marsh, H. W., Ludtke, O., Muthén, B., Asparouhov, T., Morin, A. J. S., Trautwein, U., \& Nagengast, B. (2010). A new look at the Big Five factor structure through exploratory structural equation modeling. Psychological Assessment, 22, 471-491. https://doi.org/10.1037/ a0019227.

Maslowsky, J., Jager, J., \& Hemken, D. (2015). Estimating and interpreting latent variable interactions: A tutorial for applying the latent moderated structural equations method. International Journal of Behavioral Development, 39, 87-96. https://doi.org/10.1177/ 0165025414552301.

Maslyn, J. M., \& Uhl-Bien, M. (2001). Leader-member exchange and its dimensions: Effects of self-effort and other's effort on relationship quality. Journal of Applied Psychology, 86, 697-708. https://doi. org/10.1037/0021-9010.86.4.697.

Maslyn, J. M., \& Uhl-Bien, M. (2005). LMX differentiation: Key concepts and related empirical findings. In G. B. Graen \& J. A. Graen (Eds.), Global organizing designs (LMX leadership: The series) (Vol. 3, pp. 73-98). Greenwich, CT: Information Age Publishing.

Maxwell, S. E., \& Cole, D. A. (2007). Bias in cross-sectional analyses of longitudinal mediation. Psychological Methods, 12, 23-44. https:// doi.org/10.1037/1082-989X.12.1.23.

Meyer, J. P. (2016). Handbook of employee commitment. Cheltenham, UK: Edward Elgar Publishing. https://doi.org/10.4337/ 9781784711740 .

Meyer, J. P., \& Allen, N. J. (1997). Commitment in the workplace: Theory, research, and application. Thousand Oaks, CA: Sage Publications. https://doi.org/10.4135/9781452231556.

Meyer, J. P., Allen, N. J., \& Smith, C. A. (1993). Commitment to organizations and occupations: Extension and test of a three-component conceptualization. Journal of Applied Psychology, 78, 538-551. https://doi.org/10.1037/0021-9010.78.4.538.

Meyer, J. P., Barak, I. \& Vandenberghe, C. (1996). Revised measures of affective, continuance, and normative commitment to organizations.
Unpublished manuscript. Department of Psychology, University of Western Ontario, London, Ontario, Canada.

Meyer, J. P., \& Herscovitch, L. (2001). Commitment in the workplace: Toward a general model. Human Resource Management Review, 11, 299-326. https://doi.org/10.1016/S1053-4822(00)00053-X.

Millsap, E. (2011). Statistical methods for studying measurement invariance. Abingdon, UK: Taylor \& Francis.

Muthén, L. K., \& Muthén, B. O. (2010). Mplus user's guide, version 6.1. Los Angeles, CA: Muthén \& Muthén.

Newman, D. A. (2009). Missing data techniques and low response rates: The role of systematic nonresponse parameters. In C. E. Lance \& R. J. Vandenberg (Eds.), Statistical and methodological myths and urban legends (pp. 7-36). New York, NY: Routledge.

Nielsen, M. B., Skogstad, A., Gjerstad, J., \& Einarsen, S. V. (2019). Are transformational and laissez-faire leadership related to state anxiety among subordinates? A two-wave prospective study of forward and reverse associations. Work \& Stress, 33, 137-155. https://doi.org/ 10.1080/02678373.2018.1528307.

Oyserman, D. (2001). Self-concept and identity. In A. Tesser \& N Schwarz (Eds.), Blackwell handbook of social psychology: Intraindividual processes (pp. 499-517). Oxford, UK: Blackwell Publishing.

Padilla, A., Hogan, R., \& Kaiser, R. B. (2007). The toxic triangle: Destructive leaders, susceptible followers, and conducive environments. The Leadership Quarterly, 18, 176-194. https://doi.org/10. 1016/j.leaqua.2007.03.001.

Ployhart, R. E., \& Vandenberg, R. J. (2010). Longitudinal research: The theory, design, and analysis of change. Journal of Management, 36 , 94-120. https://doi.org/10.1177/0149206309352110.

Podsakoff, P. M., MacKenzie, S. B., Lee, J.-Y., \& Podsakoff, N. P. (2003). Common method biases in behavioral research: A critical review of the literature and recommended remedies. Journal of Applied Psychology, 88, 879-903. https://doi.org/10.1037/00219010.88.5.879.

Podsakoff, P. M., MacKenzie, S. B., \& Podsakoff, N. P. (2012). Sources of method bias in social science research and recommendations on how to control it. Annual Review of Psychology, 63, 539-569. https://doi.org/10.1146/annurev-psych-120710-100452.

Pratt, M. G. (2000). The good, the bad, and the ambivalent: Managing identification among Amway distributors. Administrative Science Quarterly, 45, 456-493. https://doi.org/10.2307/2667106.

Sardeshmukh, S. R., \& Vandenberg, R. J. (2017). Integrating moderation and mediation: A structural equation modeling approach. Organizational Research Methods, 20, 721-745. https://doi.org/ 10.1177/1094428115621609.

Schaffer, B. S., \& Riordan, C. M. (2003). A review of cross-cultural methodologies for organizational research: A best-practices approach. Organizational Research Methods, 6, 169-215. https://doi. org/10.1177/1094428103251542.

Schermelleh-Engel, K., Werner, C. S., Klein, A. G., \& Moosbrugger, H. (2010). Nonlinear structural equation modeling: Is partial least squares an alternative? AStA Advances in Statistical Analysis, 94, 167-184. https://doi.org/10.1007/s10182-010-0132-3.

Schyns, B., \& Day, D. V. (2010). Critique and review of leader-member exchange theory: Issues of agreement, consensus, and excellence. European Journal of Work and Organizational Psychology, 19, 129. https://doi.org/10.1080/13594320903024922.

Schyns, B., \& Schilling, J. (2013). How bad are the effects of bad leaders? A meta-analysis of destructive leadership and its outcomes. The Leadership Quarterly, 24, 138-158. https://doi.org/10.1016/j. leaqua.2012.09.001.

Sedikides, C., \& Brewer, M. B. (2001). Individual self, relational self, collective self. Philadelphia, PA: Psychology Press.

Sedikides, C., Gaertner, L., \& O'Mara, E. M. (2011). Individual self, relational self, collective self: Hierarchical ordering of the tripartite 
self. Psychological Studies, 56, 98-107. https://doi.org/10.1007/ s12646-011-0059-0.

Seers, A., \& Graen, G. B. (1984). The dual attachment concept: A longitudinal investigation of the combination of task characteristics and leader-member exchange. Organizational Behavior and Human Performance, 33, 283-306. https://doi.org/10.1016/0030-5073(84) 90025-4.

Selenta, C., \& Lord, R. G. (2005). Development of the levels of selfconcept scale: Measuring the individual, relational, and collective levels. University of Akron: Unpublished manuscript.

Shore, L. M., Bommer, W. H., Rao, A. N., \& Seo, J. (2009). Social and economic exchange in the employee-organization relationship: The moderating role of reciprocation wariness. Journal of Managerial Psychology, 24, 701-721. https://doi.org/10.1108/ 02683940910996752.

Shore, L. M., \& Wayne, S. J. (1993). Commitment and employee behavior: Comparison of affective commitment and continuance commitment with perceived organizational support. Journal of Applied Psychology, 78, 774-780. https://doi.org/10.1037/0021-9010.78.5.774.

Siemsen, E., Roth, A., \& Oliveira, P. (2010). Common method bias in regression models with linear, quadratic, and interaction effects. Organizational Research Methods, 13, 456-476. https://doi.org/ 10.1177/1094428109351241.

Skarlicki, D. P., \& Folger, R. (1997). Retaliation in the workplace: The roles of distributive, procedural, and interactional justice. Journal of Applied Psychology, 82, 434-443. https://doi.org/10.1037/00219010.82.3.434.

Skogstad, A., Aasland, M. S., Nielsen, M. B., Hetland, J., Matthiesen, S. B., \& Einarsen, S. (2014). The relative effects of constructive, laissez-faire, and tyrannical leadership on subordinate job satisfaction: Results from two prospective and representative studies. Zeitschrift für Psychologie, 222, 221-232. https://doi.org/10.1027/ 2151-2604/a000189.

Skogstad, A., Einarsen, S., Torsheim, T., Aasland, M. S., \& Hetland, H. (2007). The destructiveness of laissez-faire leadership behavior. Journal of Occupational Health Psychology, 12, 80-92. https:// doi.org/10.1037/1076-8998.12.1.80.

Skogstad, A., Hetland, J., Glasø, L., \& Einarsen, S. (2014). Is avoidant leadership a root cause of subordinate stress? Longitudinal relationships between laissez-faire leadership and role ambiguity. Work \& Stress, 28, 323-341. https://doi.org/10.1080/02678373.2014.957362.

Spector, P. E. (2006). Method variance in organizational research: Truth or urban legend? Organizational Research Methods, 9, 221-232. https://doi.org/10.1177/1094428105284955.

Swann Jr., W. B., Chang-Schneider, C., \& Angulo, S. (2007). Selfverification in relationships as an adaptive process. In J. Wood, A. Tesser, \& J. Holmes (Eds.), Self and relationships (pp. 49-72). New York: Psychology Press.

Tepper, B. J. (2000). Consequences of abusive supervision. Academy of Management Journal, 43, 178-190. https://doi.org/10.2307/ 1556375.

Tepper, B. J. (2007). Abusive supervision in work organizations: Review, synthesis, and research agenda. Journal of Management, 33, 261289. https://doi.org/10.1177/0149206307300812.

Tyler, T. R. (2003). Justice, identity, and leadership. In D. van Knippenberg \& M. A. Hogg (Eds.), Leadership and power: Identity processes in groups and organizations (pp. 94-108). London, UK: Sage Publications.

van Knippenberg, B., \& Steensma, H. (2003). Future interaction expectation and the use of soft and hard influence tactics. Applied Psychology: An International Review, 52, 55-67. https://doi.org/ 10.1111/1464-0597.00123.

van Knippenberg, D., \& Hogg, M. A. (2003). A social identity model of leadership effectiveness in organizations. Research in
Organizational Behavior, 25, 243-295. https://doi.org/10.1016/ S0191-3085(03)25006-1.

van Knippenberg, D., van Knippenberg, B., De Cremer, D., \& Hogg, M. A. (2004). Leadership, self, and identity: A review and research agenda. The Leadership Quarterly, 15, 825-856. https://doi.org/ 10.1016/j.leaqua.2004.09.002.

Vandenberg, R. J., \& Lance, C. E. (2000). A review and synthesis of the measurement invariance literature: Suggestions, practices, and recommendations for organizational research. Organizational Research Methods, 3, 4-70. https://doi.org/10.1177/ 109442810031002.

Vroom, V. H., \& Jago, A. G. (2007). The role of the situation in leadership. American Psychologist, 62, 17-24. https://doi.org/10.1037/ 0003-066X.62.1.17.

Wang, H., Law, K. S., Hackett, R. D., Wang, D., \& Chen, Z. X. (2005). Leader-member exchange as a mediator of the relationship between transformational leadership and followers' performance and organizational citizenship behavior. Academy of Management Journal, 48, 420-432. https://doi.org/10.2307/20159668.

Wayne, S. J., Coyle-Shapiro, J. A.-M., Eisenberger, R., Liden, R. C., Rousseau, D. M., \& Shore, L. M. (2009). Social influences. In H. J. Klein, T. E. Becker, \& J. P. Meyer (Eds.), Commitment in organizations: Accumulated wisdom and new directions (pp. 253-284). New York, NY: Taylor \& Francis.

Wisse, B., \& Sleebos, E. (2016). When change causes stress: Effects of selfconstrual and change consequences. Journal of Business and Psychology, 31, 249-264. https://doi.org/10.1007/s10869-015-9411-z.

Wong, S. I., \& Giessner, S. R. (2018). The thin line between empowering and laissez-faire leadership: An expectancy-match perspective. Journal of Management, 44, 757-783. https://doi.org/10.1177/ 0149206315574597.

Wu, J. B., Tsui, A. S., \& Kinicki, A. J. (2010). Consequences of differentiated leadership in groups. Academy of Management Journal, 53, 90-106. https://doi.org/10.5465/AMJ.2010.48037079.

Xu, E., Huang, X., Lam, C. K., \& Miao, Q. (2012). Abusive supervision and work behaviors: The mediating role of LMX. Journal of Organizational Behavior, 33, 531-543. https://doi.org/10.1002/job.768.

Yammarino, F. J., Spangler, W. D., \& Bass, B. M. (1993). Transformational leadership and performance: A longitudinal investigation. The Leadership Quarterly, 4, 81-102. https://doi.org/10. 1016/1048-9843(93)90005-E.

Yang, I. (2015). Positive effects of laissez-faire leadership: Conceptual exploration. Journal of Management Development, 34, 1246-1261. https://doi.org/10.1108/JMD-02-2015-0016.

Yang, I., \& Li, M. (2017). Can absent leadership be positive in team conflicts? An examination of leaders' avoidance behavior in China. International Journal of Conflict Management, 28, 146165. https://doi.org/10.1108/IJCMA-12-2015-0083.

Yukl, G. (2010). Leadership in organizations. Upper Saddle River, NJ: Pearson.

Yukl, G., O'Donnell, M., \& Taber, T. (2009). Influence of leader behaviors on the leader-member exchange relationship. Journal of Managerial Psychology, 24, 289-299. https://doi.org/10.1108/ 02683940910952697.

Zellars, K. L., Tepper, B. J., \& Duffy, M. K. (2002). Abusive supervision and subordinates' organizational citizenship behavior. Journal of Applied Psychology, 87, 1068-1076. https://doi.org/10.1037// 0021-9010.87.6.1068.

Publisher's Note Springer Nature remains neutral with regard to jurisdictional claims in published maps and institutional affiliations. 